\title{
Multivariate Statistics and Entropy Theory for Irrigation Water Quality and Entropy-Weighted Index Development in a Subtropical Urban River, Bangladesh
}

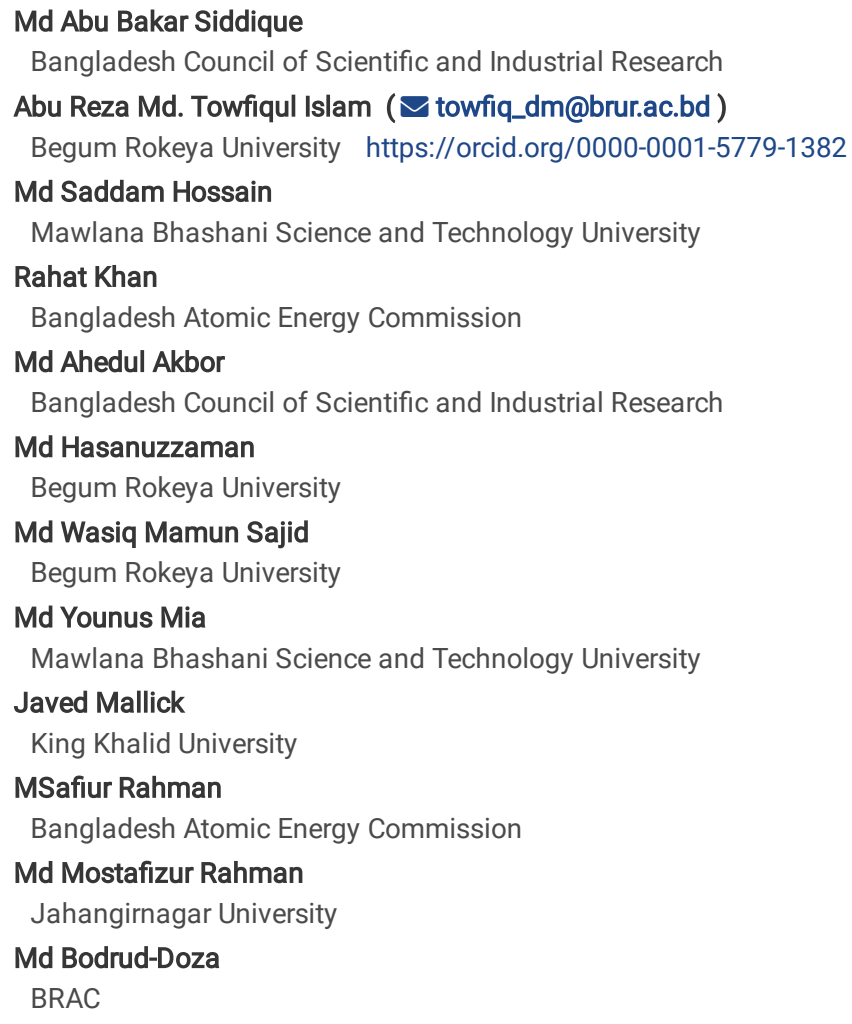

Version of Record: A version of this preprint was published at Environmental Science and Pollution Research on September 7th, 2021. See the published version at https://doi.org/10.1007/s11356-021-16343-7. 


\section{Abstract}

Currently, a well-developed combination of irrigation water quality index (IWQIs) and entropy water quality index (EWQIs) for surface water appraisal in a polluted subtropical urban river is very scarce in the literature. To close this gap, we developed IWQIs by establishing statistics-based weights of variables recommended by FAO 29 standard value using the National Sanitation Foundation Water Quality Index (NSFWQI) compared with the proposed EWQIs based on information entropy in the Dhaleshwari River, Bangladesh. Fifty surface water samples were collected from five sampling locations during the dry and wet seasons and analyzed for sixteen variables. Principal component analysis (PCA), factor analysis (FA), Moran's spatial autocorrelation, and random forest (RF) model were employed in the datasets. Weights were allocated for preliminary variables to compute IWQI-1, 2 and EWQI-1, 2 respectively. The resultant IWQIs showed an analogous trend with EWQIs and revealed poor to good quality water, with IWQI-1 for the dry season and IWQI-2 for the wet season is further suggested. The entropy theory recognized that $\mathrm{Mg}, \mathrm{Cr}$, TDS, and $\mathrm{Cl}^{-}$for the dry season and $\mathrm{Cd}, \mathrm{Cr}^{-} \mathrm{Cl}^{-}$and $\mathrm{SO}_{4}{ }^{2-}$ for the wet season are the major contaminants that affect irrigation water quality. The primary input variables were lessened to ultimately shortlisted ten variables, which revealed good performance in demonstrating water quality status since weights have come effectively from PCA than FA. The results of the $\mathrm{RF}^{-}$model depict $\mathrm{NO}_{3}{ }^{-}, \mathrm{Mg}$, and $\mathrm{Cr}^{-}$as the most predominant variables influencing surface water quality. A significant dispersed pattern was detected for IWQImin-3 in the wet season (Moran's I>0). Overall, both IWQIs and EWQIs will generate water quality control cost-effective, completely objective to establish a scientific basis of sustainable water management in the study basin.

\section{Introduction}

Water quality means its qualification for a particular reason and is controlled by class and number of disintegrated compositions (Ewaid et al. 2019). This composition acts a pivotal role in plant development and advancement either legitimately as far as insufficiency or in a roundabout way through influencing supplement accessibility (Salem et al. 2019). In this way, top-notch harvests must be yielded by high-quality irrigation water as it is straightforwardly associated with soil and plant environment (Singh et al. 2018). Therefore, timely monitoring, appraising, and forecasting of probable variations in water quality are required (Matta et al. 2020; Islam et al. 2020a).

Generally, simultaneous measurement of physical, chemical and biological water quality parameters is essential for a comprehensive surface water quality appraisal. One of the key potential issues of water quality studies is the set of variables that can be continuously monitored and related costing, collecting, analyzing and interpreting these datasets. To solve these issues, a particular water quality index (WQI) has been employed to handle the effective water quality classification using many parameters that have been widely established as informative for the end-user. Several WQI offered are highlighted by a numerical model for transforming the chosen water quality features into a dimensionless single number, generally, 0 to 100 , that gives a sign of water quality level for the end-user (Misaghi et al. 2017). Besides, it gives a comprehensive scenario to decision-makers to take the necessary steps for conserving a surface water body.

Several attempts have been undertaken by researchers worldwide to develop a universal WQI for widespread use (Sutadian et al. 2017; Matta et al. 2020; Hossain and Patra 2020; Yotova et al. 2021; Wu et al. 2021). Hence, appropriate WQI such as the irrigation water quality index (IWQI) has gained considerable attention in recent decades. However, national and international agencies have proposed several indices, for instance, US National Sanitation Foundation Water Quality Index (NSFWQI) (Brown et al. 1970), Canadian Council of Ministers of the Environment Water Quality Index (CCMEWQI) (Khan et al. 2003), and Oregon Water Quality Index (OWQI) (Tyagi et al. 2013). Of these widely use indices; the NSFWQI is the most widespread index to demarcate surface water quality in the globe (Jahin et al. 2020).

Generally, weighting approaches have been demarcated commonly into two groups, namely, subjective and objective techniques that have participatory and statistical tools. The subjective technique such as the Delphi method (Misaghi et al. 2017), analytical hierarchy process (AHP) (Sutadian et al. 2016), revised Simos' procedure (Zardari et al. 2015) provide weight to parameters based on opinions of subject experts, decision makers and various stockholders. However, a common problem of these subjective methods is ambiguity with biasness according to numbers and importance of the assigning parameters. To overcome these ambiguities, biases and subjective weight selection problems, objective techniques such as principal component analysis (PCA), and factor analysis (FA) have been taken into account that provide weights to variable based on the loading of individual variable on each factor while variables are added to select on the basis of variance elucidated by PCs (Jahin et al. 2020; Islam et al. 2020a). These techniques have been employed for generating sustainable development index (Pand et al. 2016), novel water quality index (Tripathi and Singal 2019) and so on. The main advantage for using PCA/FA is that this gives a few linear aggregations of the original variables that abridge several datasets where its inherent structure is yet kept to the highest extent promising (OCED 2008). Another benefit is that PCA/FA provides an actual interpretation of multiple analytical parameters and assists a better insight into spatiotemporal changes in water chemistry (Dutta et al. 2018). Therefore, water quality appraisal can be more reasonable and economical perspective because of basic reductions in sample timing, effort and costing needed to monitor sites for a huge number of variables (Tripathi and Singal 2019; Islam et al. 2020b).

Currently, a well-developed comprehensive IWQI to appraise river water suitability for crop production in a polluted subtropical urban river is hardly found in the literature. For example, Jahin et al. (2020) developed an IWQI in the arid and semi-arid region following FAO 29 guidelines based on the NSFWQI formula, where assigning weights were originated from PCA/FA based on the loading factor of individual indicators. One of the main limitations of the work was the insignificant sample size, which restricts its application. Similarly, Misaghi et al. (2017) introduced a new IWQI for irrigation uses based on the NSFWQI adopted by FAO 29 guidelines and applied this index to the Iranian Ghezel Ozan urban River. However, the main disadvantage is that weights were taken from the Delphi method based on expert opinion, which led to uncertainty and biases of the environmental problem in different steps of the decision-making process (Islam et al. 2017a; 2020c; Singh et al. 2020; Matta et al. 2020).

Water quality in a specific region relies on some inter-associated variables that vary in terms of geogenic and anthropogenic factors (Mandal et al. 2019). Thus, it is necessary to establish a region-specific IWQI. To avoid complexity, and uncertainty, a statistics-based objective tool including PCA/FA is necessary 
to make weights for a number of different indicators. When at least 150-300 cases are found; the PCA/FA can be an appropriate tool (Sutadian et al. 2017; Tripathi and Singal 2019). Since the PCA/FA depends on present data given for the assessment (Sutadian et al. 2016), it permits varying weights based on spatiotemporal changes in water chemistry. However, less focus has been made to assign weights according to the communality derived from the FA. Our research showcases a statistics-based tool to choose the critical influential water quality indicators by both the PCA/FA for developing IWQIs as a universal and unbiased IWQI based on selected physicochemical variables following FAO 29 standard values.

In addition to PCA/FA, this study proposed an entropy-weighted water quality (EWQI) for agricultural purposes according to information entropy and entropy weight following the DoE (1997) water quality guideline of Bangladesh. The weight-based EWQI is an enhancement over IWQIs. Information entropy measures the uncertainty in the dataset which has been successfully applied in different fields (Singh et al. 2020). In this study, for the first time, so far, the IWQIs will be employed to quantify the suitability of surface water quality and compare with the proposed EWQIs to investigate the sensitivity of the IWQIs in the polluted subtropical urban river basin, Bangladesh. Besides, the random forest model and Moran's spatial autocorrelation have been applied to examine the factor/parameter contributing to the IWQIs and their spatial patterns. Although some recent combination techniques present a reasonable outcome of surface water quality appraisal (Ewaid et al. 2019; Matta et al. 2020; Hasan et al. 2020; Yotova et al. 2021; Wu et al. 2021), such technique is yet scarce in Bangladesh. This study contributes to close this gap in the literature. Therefore, we intend to (i) determine statistics-based weights of broadly accepted parameters recommended by FAO to establish IWQI using PCA/FA concerning formula adopted by the NSFWQI, and (ii) to assess surface water suitability by the proposed EWQIs followed by Bangladesh guideline based on entropy theory; (iii) to appraise surface water quality through concurrent comparison of IWQIs and EWQIs and factor influencing on them using random forest model and (iv) to choose the most critical parameters to be added in a fast and easy and cost-effective surface water quality assessment. Thus, this study employed the index to surface water in the Dhaleshwari River basin, Bangladesh as a case study to appraise this condition of surface water quality.

\section{Data And Method}

\subsection{Study area specification}

In this study, Dhaleshwari River in Hemayetpur of Savar subdistrict, situated at the northwest part of Dhaka city, Bangladesh was investigated. The city accommodated with approximately 1.4 million of inhabitants. Our study area lies at the latitudes of $23^{\circ} 51^{\prime} 30.0024^{\prime \prime} \mathrm{N}$ and longitudes of $90^{\circ} 16^{\prime} 0.0120^{\prime \prime} \mathrm{E}$ (Fig. 1) with the land surface of an elevation of $\sim 15 \mathrm{~m}$ (Banglapedia 2018). The Dhaleshwari river is divied into two tributaries: the name Dhaleshwari remains for the northern upstream branch which combine at the southern downstream part at Manikganj district with its other branch namely Kaligonga river (Hasan et al. 2020). The divided branches are merged again before combining with the Shitalakshya river and ultimately merging with the Meghna river, which ends up in the delta of the Ganges-Brahmaputra-Meghna rivers (Ahsan et al., 2019). Three most prominent seasons are observed in the studied area: (1) the pre-monsoon season (March-June: hot and humid rainy season with temperature reaching up to $40^{\circ} \mathrm{C}$ ), (2) the monsoon or wet season (July-October: very wet with temperatures $\sim 30^{\circ} \mathrm{C}$ ), and (3) the post-monsoon or dry season (November-February: winter season with temperature 10 to $20^{\circ} \mathrm{C}$ ). Average $2000 \mathrm{~mm}$ rainfall occurs in the rainy season with average $75 \%$ humidity and $60 \%$ cloud cover (Rahman et al., 2020). The study area is comprised of Pleistocene alluvium-soil with a gentle slope heading from west to east. Land usages are mostly associated with agriculture (24.3\%), agricultural laborer (12.8\%), wage laborer (4.44\%), forestry, cattle breeding, and fishing (1.90\%), industry (1.37\%), service (20.7\%), commerce (17.4\%), transport (3.96\%), construction (1.66\%), and others (11.5\%). The total cultivable land is $\sim 16,750$ hectares with fallow land of $\sim 10,550$ hectares (Ahsan et al. 2019).

\subsection{Samples collection process}

Total 50 river-water samples were collected from 5 different sampling stations (denoted as S1, S2, S3, S4, \& S5 in Fig. 1) of the studied area during the monsoon or wet season (July-October: total 25 samples) and post-monsoon or dry season (November-February: total 25 samples) in the year of 2018 following the standard guidelines (APHA 2012). Sampling stations were chosen horizontally to cover the entire industrial area including the main effluent discharged points (S2) where the subsequent stations were $\sim 0.5 \mathrm{~km}$ apart from each other. From each sampling stations, five samples (composite samples of two/three independent collections) were collected (one sample form the center of the sampling point and other four samples around the sampling points were collected) which were separated from each other by $100-200 \mathrm{~m}$. Polyethylene plastic bottles (of $1000 \mathrm{~mL}$ ) preconditioned with $5 \%$ conc. $\mathrm{HNO}_{3}$ and rinsed with double-deionized water (Ahsan et al. 2019) were utilized to collect the river-water samples. Before the sampling, these sampling bottles were rinsed at least 3 times with the water samples to be collected at each sampling station. For collecting water samples, pre-prepared sampling bottles were submerged at $\sim 10 \mathrm{~cm}$ underneath the water-surface of the river. After sampling, the samples were immediately acidified with $2 \mathrm{~mL} \mathrm{conc}$. $\mathrm{HNO}_{3}$ per $1000 \mathrm{~mL}$ of samples $(\mathrm{Habib}$ et al. 2020; Ahsan et al. 2019), after then the bottles were screwed carefully and marked with the respective identification numbers. A same number of duplicate samples were also collected without acidification and labeled accordingly for determining the anions and some physicochemical parameters of the Dhaleswari River. All samples were then placed in an ice-bath, carried to the laboratory, and preserved in a refrigerator at $4^{\circ} \mathrm{C}$ on the same day until the analysis (Islam et al. 2020c; Ahsan et al. 2019).

\subsection{Analytical procedures}

All water samples were analyzed at the Institute of National Analytical Research and Service (INARS, ISO/IEC 17025: 2017 accredited laboratory), Bangladesh Council of Scientific and Industrial Research (BCSIR), Dhaka, Bangladesh. Before analysis, samples were allowed to reach ambient room temperature and shaken well for homogeneity. For metal analysis, water sample $(100 \mathrm{~mL})$ was taken into $250 \mathrm{~mL}$ cleaned glass-beaker by calibrated pipette, and was acidified with $5 \mathrm{~mL}$ of conc. $\mathrm{HNO}_{3}$. For digestions, samples were then heated on a hot plate $\left(150-180{ }^{\circ} \mathrm{C}\right)$, and volume was reduced to $\sim 25-30 \mathrm{~mL}$. Samples were then allowed to cool and were then transferred to $100 \mathrm{~mL}$ cleaned and calibrated volumetric flask by rinsing the beaker at least three times with double deionized water and then the flask was filled up to the mark $(100 \mathrm{~mL})$ with deionized water. Samples were then filtered and preserved in cleaned and dried nontransparent polyethylene plastic bottle $(250 \mathrm{~mL})$ with proper labeling for the determination of metals content. Multiple procedure blanks were also

Page $3 / 22$ 
prepared for quality assurance. The concentration of metals in digested samples were determined by different arrangements of atomic absorption spectrometers (Models: a. AA240 FS, b. GTA 120-AA240Z, c. SpcetrAA 220, Varian, Australia) following standard method (APHA, 2012; Ahsan et al., 2019; Siddique et al., 2020; Islam et al., 2020b), with a set of characteristic wavelengths of metals using hollow-cathode-lamps and directly aspirating the digested samples into the air-acetylene flame. Instrumental calibration was performed by analyzing the known concentrations of metals in standards. During the analysis, standard solutions or Certified Reference Material (CRM) after every 5 samples, and a method blank after 10 samples was measured to monitor the instrument's performance for error minimization. The contents of metals in each sample were measured in triplicate, and results were reported as the average $(n=3)$ contents of metals in the samples. For sample preparation, analytical reagent grade $\mathrm{HNO}_{3}$ was used as obtained from Merck, Germany. Certified reference material (CRM) for standard stock solutions of $\mathrm{Fe}, \mathrm{Pb}, \mathrm{Cr}, \mathrm{Co}, \mathrm{Cu}, \mathrm{Ni}, \mathrm{Mn}, \mathrm{Zn}, \mathrm{Hg}, \mathrm{Mg}$, As, Cd, and Ag were obtained from Fluka Analytical (Sigma Aldrich, Germany) for calibration purpose. All working solutions were prepared in double deionized water.

Collected non-acidified water samples were used for anions determination. Samples were filtered and were taken in small sample vials by syringe equipped with a 40-micron micro-filter carefully avoiding any possible sample contamination. These samples in the vials were then measured by lon-Chromatograph (Model: SIC10AVP, Shimadzu, Japan) for anions viz., $\mathrm{Cl}^{-}, \mathrm{F}^{-}, \mathrm{Br}^{-}, \mathrm{NO}_{2}{ }^{-}, \mathrm{NO}_{3}{ }^{-}$, and $\mathrm{SO}_{4}{ }^{2-}$ following standard procedure reported elsewhere (APHA, 2012; Ahsan et al., 2019, Islam et al., 2020c). For instrumental calibration, mixed-standard solution of anions prepared from CRM (Fluka Analytical, Sigma Aldrich, Germany) was used as a working standard. In this study, \% of spike recovery for all metals and anions were $90-110 \%$ which were estimated using suitable equations as reported earlier (Siddique et al. 2020).

The physicochemical parameters such as water temperature was measured in-situ using a calibrated thermometer, while DO, EC, and pH were also analyzed in-situ using portable Multi-parameter meter (Sension ${ }^{T M} 156, \mathrm{HACH}$, USA) calibrated with NIST (USA) traceable standards. Biochemical oxygen demand (BOD) was determined by 5-days period method whereas TDS was estimated gravimetrically following standard methods (Ahsan et al. 2019). Alkalinity \& hardness were estimated titrimetrically. In this study, only 16 parameters were used for both wet and dry seasons, since the FAO standard values available only for these parameters.

\subsection{Irrigation water quality index development}

\subsubsection{Selecting indicators}

After considering FAO 29 recommended limits for IWQ assessing parameters were selected (Ayers and Westcot 1994; FAO 2008). First of all, we selected the parameters based on FAO-29 method. Variables were associated with normalization by evaluating z-scores though there is concern due to being different units which is illogical to aggregate different units of two values (Tripathi and Singal 2019; Sutadian et al. 2017). To establish least data set (LDS) based on the created z-scores, PCA/FA and correlation analysis were utilized (OCED 2008). Therefore, a minimum IWQI (IWQI min) was created. We only chose values which is greater than 1 . We performed Varimax rotation to enhance factor interpretation. Under each PC, the values which are greater than 0.5 were retained. For more than one variable remnant, a multivariate correlation was performed to verify the retained variables under a single principal component. Significantlycorrelated analytical variables were considered as redundant, and we included only highest loadings. However, in case of non-correlated highly loaded variables, each of the variables was considered significant and was selected for the study.

\subsubsection{Sub-index values estimation}

The crucial and original parameters (PCA/FA) were converted to a common unit score $\left(\mathrm{S}_{\mathrm{i}}\right)$ varying between 0 and 100 according to the Eq. (1):

$$
\mathrm{S}_{\mathrm{i}}=\left[1-\frac{\left(\mathrm{Va}-\mathrm{V}_{\mathrm{i}}\right)}{\left(\mathrm{V}_{\mathrm{s}}-\mathrm{V}_{\mathrm{i}}\right)}\right] \times 100
$$

Where, $\mathrm{Va}$ is the actual laboratory measurement value, $\mathrm{Vs}$ is the recommended value of FAO guidelines, and Vi is the ideal value for pure-water (7.0 for pH and zero for other analytical parameters).

\subsubsection{Establishing parameter weights}

Based on PCA/FA, a weight value $\left(\mathrm{W}_{\mathrm{i}}\right)$ for each parameter was attained. Then, weights were distributed on two approaches; in first approach, the eigen-values for each principal component and factor loadings for each parameter from PCA were utilized (IWQI-1) (Wang et al., 2017). Then communality of each indicator after FA was employed (IWQI-2) described by Jahin et al. (2020). The portions of variance elucidated by each indicator was indicated by communality value which varies between 0 and 1 where, high value implies greater contribution (Härdle and Simar 2015). Weight values were then extracted from the ratio of communality of each indicator to the sum of all indicator's communalities. As for 3 IWQI ${ }_{\mathrm{min}}$, weights were estimated by using 3 tools communalities (IWQI $\mathrm{min}_{\text {- }}$ $\left.{ }_{1}\right)$, variance (IWQI $\mathrm{min}_{-2}$ ), and eigen-values and factor loadings (IWQI $I_{\mathrm{min}-3}$ ). IWQI $\mathrm{min}_{\mathrm{m}-2}$ weights were extracted from the ratio between the variation of each individual PC (\%) and the total \% of variation of all PCs with eigen-vectors more than 1 . Weights for IWQI min-3 $_{3}$ were estimated based on the eigen-values for each PCs and factor loading for each individual parameter remained in LDS.

\subsubsection{Final index and quality remarks}

Irrigation water quality index (IWQI) is a robust tool (Xiao et al. 2014). The ultimate indices were computed by accumulation of scores \& weights in a single dimensionless value: 
The ultimate index varied between 0 and 100, with high values demonstrating good water-quality. Following Jahin et al. (2020), the water quality can be demarcated as excellent (91-100), good (71-90), moderate (51-70), low (26-50), and poor (0-25), respectively.

\subsection{Development of entropy water quality index (EWQI)}

In information entropy theory (Shannon 1948), entropy is taken as an estimation of uncertainty. It is adopted to detect the weight of each variable, which could decrease the error triggering from omitting the artificial weight (Pei-Yue et al. 2010). The entropy theory denotes how much a probabilistic method can be stochastic (Islam et al. 2017b). In this research, the EWQI is employed to show the river-water quality due to its acceptance, aptness, robustness and consistency (Islam et al. 2020b; Amiri et al. 2014). Entropy weight is a widely used tool to represent the variable's weights, and 3 steps are used to estimate the EWQI. The equations are described briefly with steps (Islam et al. 2020a)

\subsection{Random forest model}

Breiman (2001) developed the tree-based supervised artificial intelligence random forest (RF) model. The RF model was run in this study using the package of "randomForest" under the free R statistical software (R Development Core Team 2014). This model was used as a feature selection tool to identify variable importance from the dataset and has some benefits in studying variable association compared to other machine learning models such as artificial neuron network and support vector machine (Rahman and Islam 2019; Rahman et al. 2020; Islam et al. 2020d and Salam and Islam 2020). The RF model provides good, robust and relatively accurate outcomes than other models. A detailed mathematical computation and theoretical basis of the RF model can be found in Breiman (2001). In this work, the mean decrease in Gini values was employed to measure the relative importance of various physicochemical variables. A lower Gini value denotes less important input variables (Islam et al. 2020d). Thus, this model was applied to explore the importance degree of physicochemical parameters affecting the surface-water quality during the dry and wet seasons in the polluted subtropical river.

\subsection{Statistical analyses}

Spatial autocorrelation e.g., Moran's I index was used to assess the spatial distribution pattern of the surface-water quality indices. This statistical approach involves global-spatial auto-correlation analysis, that represents the total spatial association for the studied locations. Local spatial auto-correlation represents the level of spatial auto-correlation in a specific site. Moran's I index is a parametric tool that represents auto-correlation varied from -1 to +1 and generates p-value \& Z-score to appraise the degree of auto-correlation (Liu and Mao 2020; Islam et al. 2020a). A negative Moran's value indicates the data dispersed randomly whereas positive Moran's value indicates the data clustered spatially in the datasets (Islam et al. 2017a). In addition, Moran's I index was checked based on 999 transformations at the significance level of $p<0.05$. The details about the computation process of the Moran's I index can be observed elsewhere (Liu and Mao 2020).

Statistical approaches were performed by SPSS statistical package (version 25) for Windows. Kolmogorov-Smirnov test was run to check data normality \& homogeneity of surface water for both dry and wet seasons. Pearson's correlation matrix was calculated to check the association between the analyzed hydrochemical variables. The coefficient of determination $\left(R^{2}\right)$ was utilized to estimate the goodness of fit of the tested models. Root mean square error (RMSE) of the model was computed to assess the predictive capability of all the models. A paired sample $t$-test was run to establish the statistical differences in seasons' concentrations of physicochemical parameters.

\section{Results}

\subsection{Water quality status}

The descriptive statistical outcomes of all the sixteen physicochemical variables including nine trace metal concentrations of 50 surface water samples from five sampling locations for dry and wet seasons are tabulated in Table 1. Physicochemical variables reflect the water type, quality, and characteristics of surface water (Islam et al. 2020a). pH mainly controls surface water chemistry such as alkalinity, chemical condition, and solubility of dissolved metals. During the dry season, the $\mathrm{pH}$ values of water samples varied from 7.49 to 9.87 with a mean of $8.07 \pm 0.64$, while, in the wet season, the $\mathrm{pH}$ value ranged from 7.28 to 7.66 with a mean of $7.51 \pm 0.10$, indicating slight alkalinity. This is because of the elevated influx of $\mathrm{NO}_{3}{ }^{-}$and $\mathrm{SO}_{4}{ }^{-}$from industrial activities (Islam et al. 2017b; Hasan et al. 2020). In the dry season, the mean value of pH, EC, and TDS were 8.07 (range: 7.28-9.87), 1.15 (dS/m) (range: 0.71-3.1), and 809.24 (mg/L) (range: 388-3423), respectively. The mean value of $\mathrm{pH}$ (8.07) surpassed $40 \%$ of the FAO standard range for irrigation in the dry season (Ayers and Westcot 1994; FAO 2008). The EC varied from 0.71 to $3.1 \mathrm{dSm}^{-1}$, and elevated EC values were due to the effluent of industrial water into the irrigation system in the dry season. However, the TDS value crossed $12 \%$ of the FAO standard limit for irrigation in the dry season. The elevated contents of EC, and TDS of the study sites in the dry season are due to the impact of pollutants from the textile, tannery, petrochemical, and automobile, and agricultural inputs in the lands beside the river, urban waste, and municipal wastes (Mandal et al. 2017). The mean concentrations of $\mathrm{Mg}(20.69 \mathrm{mg} / \mathrm{L}), \mathrm{Cl}^{-}(108.38 \mathrm{mg} / \mathrm{L})$, and SO${ }_{4}^{2-}(177.27$ $\mathrm{mg} / \mathrm{L})$ were also found within the $\mathrm{FAOs}^{\prime}$ standard except for $\mathrm{NO}_{3}{ }^{-}(36.95 \mathrm{mg} / \mathrm{L})$. The elevated contents of $\mathrm{SO}_{4}{ }^{2-}$ in the dry season may be due to the low river flow and the high evaporation of water which is evident in the effect of discharged effluent into the Dhaleshwari River (Hasan et al. 2020). The $\mathrm{NO}_{3}$ concentrations in the study sites surpassed $80 \%$ of the FAOs' guideline value. Possible sources of high $\mathrm{NO}_{3}{ }^{-}$may be derived from fertilizers, animal waste, septic tanks, sewage treatment facilities and rotting plant litter (Ahmed et al. 2019; Islam et al. 2017a). On the other hand, in the wet season, the abovementioned water quality parameters were diluted. The mean value of $\mathrm{pH}$ become 7.51 followed by the decreased concentration of EC; $0.16 \mathrm{dS} / \mathrm{m}$, TDS; 87.64 $\mathrm{mg} / \mathrm{L}, \mathrm{Cl} ; 7.35 \mathrm{mg} / \mathrm{L}, \mathrm{NO}_{3} ; 2.68 \mathrm{mg} / \mathrm{L}$, and $\mathrm{SO}_{4}{ }^{2-} ; 15.08 \mathrm{mg} / \mathrm{L}$ and $\mathrm{Mg}^{2+} ; 5.95 \mathrm{mg} / \mathrm{L}$, respectively in the wet season. In addition, the concentration of metals $(\mathrm{Pb}, \mathrm{Cd}, \mathrm{Cr}, \mathrm{Mn}, \mathrm{Fe}, \mathrm{Co}, \mathrm{Cu}, \mathrm{Zn}$, and $\mathrm{As})$ in water samples were determined for both seasons. Results revealed that except $\mathrm{Cr}(0.58 \mathrm{mg} / \mathrm{L})$ and $\mathrm{Mn}(0.42 \mathrm{mg} / \mathrm{L})$ in 
the dry season, the mean concentrations of all the other metals were found within the standard value recommended by the FAO guideline. However, in the wet season, all the studied metals were within the recommended levels in the river water, but in the dry season, $76 \%$, $88 \%$ and $4 \%$ samples exceeded the Cr, Mn, and $\mathrm{Cu}$ concentrations recommended by FAO, respectively (FAO 2008). In some of the water samples, concentrations of studied metals were enough to make surface water unsuitable for irrigation except for $\mathrm{As}, \mathrm{Pb}$, and $\mathrm{Cd}$ as their contents were lower than the FAO standard limit for irrigation purposes. The variations in amounts of analyzed parameters were accounted for the locations of the sluice gate from the point source to collection points and also for seasonal variations were a dominant factor which resulted in the Dhaleshwari River's increase in contamination level. 
Table 1

Descriptive statistics of water quality parameters in the polluted subtropical river for dry and wet seasons

\begin{tabular}{|c|c|c|c|c|c|c|c|c|c|c|c|c|}
\hline \multicolumn{13}{|l|}{ Dry season } \\
\hline Parameter & Unit & $\begin{array}{l}\text { Mean } \pm \\
\text { STD }\end{array}$ & Min & Max & CV (\%) & Skewness & Kurtosis & $\begin{array}{l}\text { KS } \\
\text { Test }\end{array}$ & $\begin{array}{l}\text { FAO } \\
\text { standard } \\
(2008)\end{array}$ & $\begin{array}{l}\text { DoE } \\
\text { Standard } \\
\text { (1997) }\end{array}$ & $\begin{array}{l}\text { Information } \\
\text { entropy }\left(e_{j}\right)\end{array}$ & $\begin{array}{l}\text { Weight } \\
\text { entropy } \\
\text { (wj) }\end{array}$ \\
\hline $\mathrm{pH}$ & & $\begin{array}{l}8.07 \pm \\
0.64\end{array}$ & 7.49 & 9.87 & 7.95 & 1.1 & 0.68 & 0 & $6.5-8.4$ & $6.5-8.5$ & 0.83 & 0.06 \\
\hline EC & $\begin{array}{l}\mathrm{dS} \\
\mathrm{m}^{-1}\end{array}$ & $\begin{array}{l}1.15 \pm \\
0.62\end{array}$ & 0.71 & 3.1 & 53.61 & 2.16 & 4.53 & 0 & 3 & - & 0.79 & 0.07 \\
\hline TDS & $\mathrm{mgL}_{1}^{-}$ & $\begin{array}{l}809.24 \pm \\
794.01\end{array}$ & 388 & 3423 & 98.12 & 2.55 & 5.74 & 0 & 2000 & 1000 & 0.67 & 0.11 \\
\hline $\mathrm{Pb}$ & $\mathrm{mgL}_{1}^{-}$ & $\begin{array}{l}0.002 \pm \\
0.001\end{array}$ & 0 & 0.005 & 86.34 & 1.28 & 0.85 & 0.065 & 5 & 0.05 & 0.87 & 0.04 \\
\hline $\mathrm{Cd}$ & $\mathrm{mgL}_{1}^{-}$ & $<0.001$ & & & 96.47 & 1.11 & -0.01 & 0.002 & 0.01 & 0.005 & 0.86 & 0.05 \\
\hline $\mathrm{Cr}$ & $\mathrm{mgL}_{1}^{-}$ & $\begin{array}{l}0.58 \pm \\
1.20\end{array}$ & 0.02 & 4.71 & 205.9 & 3 & 8.27 & 0 & 0.1 & 0.05 & 0.64 & 0.12 \\
\hline $\mathrm{Mn}$ & $\mathrm{mgL}_{1}^{-}$ & $\begin{array}{l}0.42 \pm \\
0.37\end{array}$ & 0.09 & 1.34 & 87.32 & 1.72 & 1.68 & 0 & 0.2 & 0.1 & 0.86 & 0.05 \\
\hline $\mathrm{Fe}$ & $\mathrm{mgL}_{1}^{-}$ & $\begin{array}{l}1.10 \pm \\
1.31\end{array}$ & 0.09 & 4.64 & 119.23 & 1.57 & 1.61 & 0 & 5 & $0.3-1.0$ & 0.78 & 0.07 \\
\hline Co & $\mathrm{mgL}_{1}^{-}$ & $\begin{array}{l}0.016 \pm \\
0.007\end{array}$ & 0 & 0.03 & 44.28 & -0.09 & -0.63 & 0.2 & 0.05 & - & 0.95 & 0.01 \\
\hline $\mathrm{Cu}$ & $\mathrm{mgL}_{1}^{-}$ & $\begin{array}{l}0.04 \pm \\
0.05\end{array}$ & 0 & 0.2 & 127.67 & 2.21 & 4.29 & 0 & 0.2 & 11 & 0.8 & 0.06 \\
\hline $\mathrm{Zn}$ & $\mathrm{mgL}_{1}^{-}$ & $\begin{array}{l}0.16 \pm \\
0.17\end{array}$ & 0.01 & 0.64 & 108.3 & 2.39 & 4.45 & 0 & 2 & 5 & 0.86 & 0.04 \\
\hline As & $\mathrm{mgL}_{1}^{-}$ & $\begin{array}{l}0.007 \pm \\
0.002\end{array}$ & 0.001 & 0.01 & 33.47 & -1.01 & 0.37 & 0.031 & 0.1 & 0.05 & 0.97 & 0.01 \\
\hline $\mathrm{Mg}$ & $\mathrm{mgL}_{1}^{-}$ & $\begin{array}{l}20.69 \pm \\
22.18\end{array}$ & 12.13 & 112.4 & 107.17 & 3.64 & 13.44 & 0 & 60 & $30-35$ & 0.55 & 0.14 \\
\hline $\mathrm{Cl}-$ & $\mathrm{mgL}_{1}^{-}$ & $\begin{array}{l}108.38 \pm \\
100.11\end{array}$ & 53.19 & 558.4 & 92.37 & 4.1 & 18.51 & 0 & 1065 & $150-600$ & 0.74 & 0.08 \\
\hline $\mathrm{NO}_{3}^{-}$ & $\mathrm{mgL}_{1}^{-}$ & $\begin{array}{l}36.95 \pm \\
27.19\end{array}$ & 2.33 & 113.66 & 73.57 & 1.07 & 1.46 & 0.134 & 10 & $<1$ & 0.9 & 0.03 \\
\hline $\mathrm{SO}_{4}^{2-}$ & $\mathrm{mgL}_{1}^{-}$ & $\begin{array}{l}177.27 \pm \\
133.81\end{array}$ & 71.09 & 568.3 & 75.49 & 1.41 & 1.46 & 0 & 960 & 400 & 0.78 & 0.07 \\
\hline \multicolumn{13}{|l|}{ Wet season } \\
\hline Parameter & Unit & $\begin{array}{l}\text { Mean } \pm \\
\text { STD }\end{array}$ & Min & Max & CV\% & Skewness & Kurtosis & $\begin{array}{l}\text { KS } \\
\text { Test }\end{array}$ & $\begin{array}{l}\text { FAO } \\
\text { standard } \\
(2008)\end{array}$ & $\begin{array}{l}\text { DoE } \\
\text { Standard } \\
(1997)\end{array}$ & $\begin{array}{l}\text { Information } \\
\text { entropy }\left(e_{j}\right)\end{array}$ & $\begin{array}{l}\text { Weight } \\
\text { entropy } \\
\text { (wj) }\end{array}$ \\
\hline $\mathrm{pH}$ & & $\begin{array}{l}7.51 \pm \\
0.10\end{array}$ & 7.28 & 7.66 & 1.36 & -0.81 & -0.14 & 0.063 & $6.5-8.4$ & $6.5-8.5$ & 0.96 & 0.03 \\
\hline EC & $\begin{array}{l}\mathrm{dS} \\
\mathrm{m}^{-1}\end{array}$ & $\begin{array}{l}0.16 \pm \\
0.01\end{array}$ & 0.14 & 0.19 & 6.91 & 0.47 & -0.49 & 0.096 & 3 & - & 0.94 & 0.05 \\
\hline TDS & $\begin{array}{l}m g \\
L^{-1}\end{array}$ & $\begin{array}{l}87.64 \pm \\
6.70\end{array}$ & 77 & 100 & 7.64 & 0.3 & -0.97 & 0.192 & 2000 & 1000 & 0.93 & 0.06 \\
\hline $\mathrm{Pb}$ & $\begin{array}{l}m g \\
L^{-1}\end{array}$ & $<0.01$ & & & 46.58 & 0.6 & 0 & 0.2 & 5 & 0.05 & 0.93 & 0.06 \\
\hline
\end{tabular}




\begin{tabular}{|c|c|c|c|c|c|c|c|c|c|c|c|c|}
\hline \multicolumn{13}{|c|}{ Dry season } \\
\hline $\mathrm{Cd}$ & $\begin{array}{l}\mathrm{mg} \\
\mathrm{L}^{-1}\end{array}$ & $<0.001$ & & & 128.95 & 3.9 & 17.41 & 0.001 & 0.01 & 0.005 & 0.84 & 0.14 \\
\hline $\mathrm{Cr}$ & $\begin{array}{l}\mathrm{mg} \\
\mathrm{L}^{-1}\end{array}$ & $\begin{array}{l}0.02 \pm \\
0.01\end{array}$ & 0.01 & 0.05 & 44.7 & 3.12 & 11.56 & 0 & 0.1 & 0.05 & 0.86 & 0.12 \\
\hline $\mathrm{Mn}$ & $\begin{array}{l}\mathrm{mg} \\
\mathrm{L}^{-1}\end{array}$ & $\begin{array}{l}0.07 \pm \\
0.03\end{array}$ & 0.01 & 0.12 & 41.51 & -0.1 & -0.23 & 0.2 & 0.2 & 0.1 & 0.95 & 0.04 \\
\hline $\mathrm{Fe}$ & $\begin{array}{l}\mathrm{mg} \\
\mathrm{L}^{-1}\end{array}$ & $\begin{array}{l}3.51 \pm \\
1.66\end{array}$ & 0.41 & 6.42 & 47.26 & -0.27 & -0.69 & 0.144 & 5 & $0.3-1.0$ & 0.95 & 0.05 \\
\hline Co & $\begin{array}{l}\mathrm{mg} \\
\mathrm{L}^{-1}\end{array}$ & $\begin{array}{l}0.007 \pm \\
0.004\end{array}$ & 0.001 & 0.013 & 53.19 & -0.18 & -0.87 & 0.2 & 0.05 & - & 0.92 & 0.06 \\
\hline $\mathrm{Cu}$ & $\begin{array}{l}\mathrm{mg} \\
\mathrm{L}^{-1}\end{array}$ & $\begin{array}{l}0.014 \pm \\
0.009\end{array}$ & 0.001 & 0.031 & 62.03 & 0.37 & -0.75 & 0.2 & 0.2 & 11 & 0.93 & 0.06 \\
\hline $\mathrm{Zn}$ & $\begin{array}{l}\mathrm{mg} \\
\mathrm{L}^{-1}\end{array}$ & $\begin{array}{l}0.07 \pm \\
0.04\end{array}$ & 0.01 & 0.16 & 55.89 & 0.49 & 0.54 & 0.2 & 2 & 5 & 0.93 & 0.06 \\
\hline As & $\begin{array}{l}\mathrm{mg} \\
\mathrm{L}^{-1}\end{array}$ & $\begin{array}{l}0.003 \pm \\
0.001\end{array}$ & 0.002 & 0.004 & 19.62 & -0.16 & -0.91 & 0.2 & 0.1 & 0.05 & 0.95 & 0.04 \\
\hline $\mathrm{Mg}$ & $\begin{array}{l}\mathrm{mg} \\
\mathrm{L}^{-1}\end{array}$ & $\begin{array}{l}5.95 \pm \\
0.79\end{array}$ & 4.57 & 7.95 & 13.32 & 0.76 & 0.91 & 0.2 & 60 & $30-35$ & 0.95 & 0.04 \\
\hline $\mathrm{Cl}-$ & $\begin{array}{l}\mathrm{mg} \\
\mathrm{L}^{-1}\end{array}$ & $\begin{array}{l}7.35 \pm \\
4.41\end{array}$ & 1.94 & 15.74 & 60.08 & 0.18 & -1.35 & 0.02 & 1065 & $150-600$ & 0.88 & 0.1 \\
\hline $\mathrm{NO}_{3}^{-}$ & $\begin{array}{l}\mathrm{mg} \\
\mathrm{L}^{-1}\end{array}$ & $\begin{array}{l}2.68 \pm \\
0.97\end{array}$ & 0.69 & 4.6 & 36.19 & -0.19 & -0.72 & 0.2 & 10 & $<1$ & 0.96 & 0.04 \\
\hline $\mathrm{SO}_{4}{ }^{2-}$ & $\begin{array}{l}\mathrm{mg} \\
\mathrm{L}^{-1}\end{array}$ & $\begin{array}{l}15.08 \pm \\
1.91\end{array}$ & 12.27 & 19.47 & 12.69 & 0.55 & -0.4 & 0.2 & 960 & 400 & 0.93 & 0.06 \\
\hline
\end{tabular}

EC, electrical conductivity; SD, standard deviation; CV, coefficient of variation.

\subsection{Principal component analysis for water quality parameter selection}

The first five components (PCs) had eigenvalues above 1 and were accounted for $89.73 \%$ of the variance of datasets for the dry season (Table 2). PC1 (first) explained $35.13 \%$ of the total variance with an eigenvalue of 5.97. It added the most important variables influencing water chemistry in the study area, i.e., pH, $\mathrm{EC}, \mathrm{Mn}, \mathrm{Fe}$, and $\mathrm{SO}_{4}{ }^{2-}$. These variables were well-associated and coherence with each other (Table 2), only EC and $\mathrm{SO}_{4}{ }^{2-}$ were taken into consideration for the least dataset (LDS). The PC2 (second) elucidated $26.65 \%$ of the variance with an eigenvalue of 4.53 . The PC2 was predominated by trace metals of mixed sources, including TDS, $\mathrm{Cr}, \mathrm{Cu}, \mathrm{Co}, \mathrm{NO}_{3}{ }^{-}$. The maximum-loaded variable; TDS and $\mathrm{Cr}$ were kept for LDS because of its strong significant association with each other. The PC3 (third) represented $12.30 \%$ of the variance with an eigenvalue of 2.09 . The PC3 was predominated by $\mathrm{Pb}, \mathrm{Cd}$, and $\mathrm{Cl}^{-}$. Because of the strong significant association among these parameters, all of them were retained for the LDS. The PC4 (four) responsible for $9.47 \%$ of the variance with an eigenvalue of 1.61. This PC4 was predominated by well-associated two parameters, i.e, $\mathrm{Mg}$ and $\mathrm{NO}_{3}{ }^{-}$and thus both the maximum-loaded parameters were retained for the LDS. The PC5 (five) responsible for $6.16 \%$ of the variance with an eigenvalue of 1.05 . Under the PC5, As, Co and Zn were elevated loaded and also, they did not exhibit a significant association with each other, and hence the highest loaded element e.g., Zn was taken for LDS because industrial wastes attributed to Zn solely in the Dhaleswari River basin (Islam et al. 2020a).

The results of PCA reveal that the first 5 PCs had eigenvalues exceeded 1, and were accounted for $82.52 \%$ of the variance of the dataset in the wet season. The PC1 (first) explained $32.84 \%$ of the total variance with an eigenvalue of 5.25 . It added the most important parameters e.g., $\mathrm{EC} \mathrm{TDS} \mathrm{Cl}^{-}$, $\mathrm{NO}_{3}{ }^{-}$and $^{-} \mathrm{SO}_{4}{ }^{2-}$ affecting the surface water chemistry in the study site (Table 2). Though they were well-associated with each other, only the higher loaded EC, $\mathrm{TDS}$, and $\mathrm{NO}_{3}{ }^{-}$ were chosen for LDS. The PC2 (second) elucidated $24.06 \%$ of the total variance with an eigenvalue of 3.85 . The PC2 was predominated by $\mathrm{pH}$, Pb, Mn, and Fe. Only $\mathrm{Pb}$ and $\mathrm{Mn}$ were retained for LDS because of the higher loaded value. The PC3 (third) responsible for $11.33 \%$ with an eigenvalue of 1.81 , which was dominated by $\mathrm{Co}, \mathrm{Cu}$, and As. Cobalt, showed a strong significant positive association with Cu but As exhibited a negative association with them. Because of the strong significant positive association and the higher loaded value, Co and Cu were retained for LDS. The PC4 (four) elucidated for $8.18 \%$ of the variance with an eigenvalue of 1.31. It was predominated by three parameters including $\mathrm{Cd}, \mathrm{Mg}^{2+}$ and $\mathrm{Zn} . \mathrm{Mg}^{2+}$ and $\mathrm{Zn}$ had higher loaded variables; however, Cd did not show any significant association with $\mathrm{Mg}^{2+}$, and $\mathrm{Zn}$. Thus, $\mathrm{Mg}^{2+}$ and $\mathrm{Zn}$ were chosen for the LDS. The PC5 (five) explained for $6.10 \%$ of the variance with an eigenvalue 1.08. Chromium had the highest loading value and retained for LDS. 
Table 2

Varimax rotated component matrix for water quality parameters for dry and wet seasons

\begin{tabular}{|c|c|c|c|c|c|c|c|c|c|}
\hline \multicolumn{10}{|l|}{ Dry Season } \\
\hline Parameter & PC1 & PC2 & PC3 & PC4 & PC5 & & & & \\
\hline Eigen Value & 5.97 & 4.53 & 2.09 & 1.61 & 1.05 & & & & \\
\hline Variance, \% & $35.13 \%$ & $26.65 \%$ & $12.30 \%$ & $9.47 \%$ & $6.16 \%$ & & & & \\
\hline Cumulative, \% & $35.13 \%$ & $61.78 \%$ & $74.09 \%$ & $83.56 \%$ & $89.73 \%$ & & & & \\
\hline Indicators & \multicolumn{5}{|c|}{ Eigen vectors } & Com1 & $w_{i}$ & Com2 & $W_{i(\min -1)}$ \\
\hline $\mathrm{pH}$ & 0.27 & 0.20 & -0.03 & -0.30 & -0.08 & 0.77 & 0.05 & & \\
\hline EC & 0.33 & 0.23 & -0.02 & 0.15 & 0.02 & 0.93 & 0.06 & 0.90 & 0.11 \\
\hline TDS & 0.29 & 0.31 & 0.00 & 0.01 & -0.09 & 0.95 & 0.07 & 0.94 & 0.12 \\
\hline $\mathrm{Pb}$ & 0.22 & -0.23 & 0.34 & -0.06 & -0.12 & 0.87 & 0.06 & 0.86 & 0.11 \\
\hline $\mathrm{Cd}$ & 0.17 & -0.11 & 0.58 & -0.15 & 0.12 & 0.88 & 0.06 & 0.69 & 0.09 \\
\hline $\mathrm{Cr}$ & 0.26 & 0.34 & 0.02 & -0.05 & -0.12 & 0.95 & 0.07 & 0.92 & 0.12 \\
\hline $\mathrm{Mn}$ & 0.27 & -0.30 & -0.18 & 0.13 & 0.00 & 0.94 & 0.07 & & \\
\hline $\mathrm{Fe}$ & 0.28 & -0.27 & -0.14 & -0.01 & 0.04 & 0.86 & 0.06 & & \\
\hline Co & 0.16 & 0.20 & -0.02 & -0.26 & -0.55 & 0.84 & 0.06 & & \\
\hline $\mathrm{Cu}$ & -0.31 & 0.26 & -0.13 & 0.15 & 0.04 & 0.90 & 0.06 & & \\
\hline $\mathrm{Zn}$ & 0.09 & -0.08 & 0.01 & 0.47 & 0.69 & 0.94 & 0.07 & 0.29 & 0.04 \\
\hline As & -0.34 & 0.14 & -0.02 & -0.04 & 0.17 & 0.85 & 0.06 & & \\
\hline $\mathrm{Mg}^{2+}$ & 0.16 & 0.26 & 0.16 & 0.50 & -0.16 & 0.94 & 0.07 & 0.92 & 0.12 \\
\hline $\mathrm{Cl}-$ & 0.20 & 0.26 & 0.33 & -0.33 & -0.16 & 0.89 & 0.06 & 0.79 & 0.10 \\
\hline $\mathrm{NO}_{3}^{-}$ & -0.06 & 0.24 & 0.20 & 0.41 & -0.09 & 0.89 & 0.06 & 0.85 & 0.11 \\
\hline $\mathrm{SO}_{4}^{2-}$ & 0.37 & 0.10 & -0.15 & -0.12 & 0.03 & 0.92 & 0.06 & 0.83 & 0.10 \\
\hline Parameter & PC1 & PC2 & PC3 & PC4 & PC5 & & & & \\
\hline Eigen Value & 5.25 & 3.85 & 1.81 & 1.31 & 1.08 & & & & \\
\hline Variance, \% & $32.84 \%$ & $24.06 \%$ & $11.33 \%$ & $8.18 \%$ & $6.10 \%$ & & & & \\
\hline Cumulative, \% & $32.84 \%$ & $56.90 \%$ & $68.23 \%$ & $76.42 \%$ & $82.52 \%$ & & & & \\
\hline Indicators & Eigen ve & & & & & com1 & $\mathbf{w}_{\mathbf{i}}$ & com2 & $\mathrm{W}_{\mathrm{i}(\min -1)}$ \\
\hline $\mathrm{pH}$ & 0.28 & 0.27 & -0.03 & 0.00 & -0.22 & 0.69 & 0.06 & & \\
\hline EC & 0.40 & 0.08 & 0.15 & -0.15 & 0.16 & 0.93 & 0.08 & 0.95 & 0.11 \\
\hline TDS & 0.38 & 0.04 & 0.10 & -0.20 & 0.01 & 0.84 & 0.07 & 0.91 & 0.11 \\
\hline $\mathrm{Pb}$ & -0.19 & 0.35 & -0.20 & 0.17 & -0.08 & 0.78 & 0.06 & 0.86 & 0.10 \\
\hline $\mathrm{Cd}$ & 0.02 & 0.20 & -0.38 & 0.33 & -0.45 & 0.56 & 0.05 & & \\
\hline $\mathrm{Cr}$ & 0.11 & -0.10 & -0.32 & 0.33 & 0.63 & 0.47 & 0.04 & 0.74 & 0.09 \\
\hline $\mathrm{Mn}$ & -0.28 & 0.35 & 0.02 & -0.02 & 0.26 & 0.90 & 0.07 & 0.88 & 0.11 \\
\hline $\mathrm{Fe}$ & -0.30 & 0.33 & -0.06 & -0.06 & 0.12 & 0.91 & 0.07 & & \\
\hline Co & -0.03 & 0.29 & 0.39 & 0.15 & -0.09 & 0.64 & 0.05 & 0.72 & 0.09 \\
\hline $\mathrm{Cu}$ & -0.20 & 0.14 & 0.40 & -0.26 & 0.21 & 0.67 & 0.05 & 0.60 & 0.07 \\
\hline As & 0.00 & -0.38 & 0.27 & -0.36 & 0.28 & 0.67 & 0.05 & & \\
\hline $\mathrm{Mg}^{2+}$ & -0.10 & 0.25 & 0.29 & 0.36 & 0.08 & 0.79 & 0.06 & 0.78 & 0.09 \\
\hline $\mathrm{Cl}-$ & 0.31 & 0.31 & 0.00 & 0.20 & 0.01 & 0.91 & 0.07 & & \\
\hline
\end{tabular}




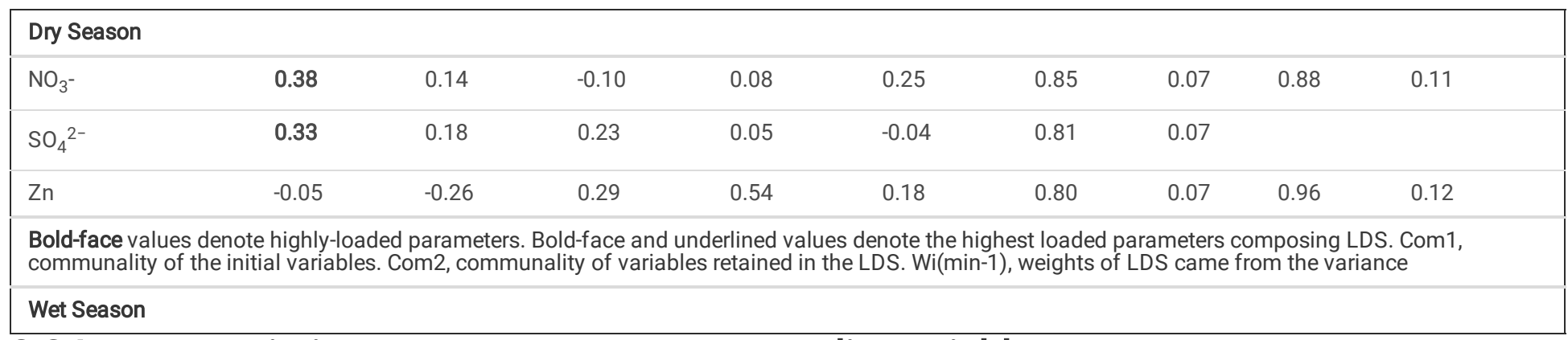

\subsection{Inter-associations among entropy water quality variables}

Before assessing the IWQ of all water samples from the study sites, the entropy theory was used to appraise surface water quality. It is essential to recognize the association between information entropy and entropy weight with the analyzed parameters. It is well-known that physicochemical variables with lower entropy weight and optimal information entropy value have little influence on overall water quality (Islam et al. 2017a; 2020c; Habib et al. 2020). However, the entropy value lessens the relative error retained by ignoring the artificial weight and considering objective weighing. This entropy value ignores the likely weight consideration via a robust and consistent weighting method. The findings of the entropy weight and information entropy weight for the 15 tested parameters are outlined in Table 1. Results showed that $\mathrm{Mg}, \mathrm{Cr}$, TDS, and $\mathrm{Cl}^{-}$had a greater significant influence on surface water quality during the dry season in the Dhaleswari River basin. These had a comparatively lesser entropy information value and the larger entropy weight among the physicochemical

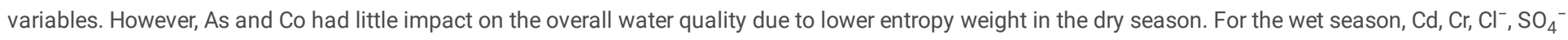
and TDS had a higher influence on water quality in the study sites because of the higher entropy weight and lower entropy information value among all water quality parameters. While, it is also observed that $\mathrm{NO}_{3}{ }^{-}$and $\mathrm{pH}$ had little influence on the surface water quality in the wet season. The magnitude to influence physicochemical variables on surface water quality is followed in the descending order: $\mathrm{Mg}>\mathrm{Cr}>\mathrm{TDS}>\mathrm{Cl}^{-}>\mathrm{SO}_{4}{ }^{2+}>\mathrm{EC}>\mathrm{Fe}>\mathrm{pH}>\mathrm{Cu}>\mathrm{Mn}>\mathrm{Cd}>\mathrm{Pb}>\mathrm{Zn}>$

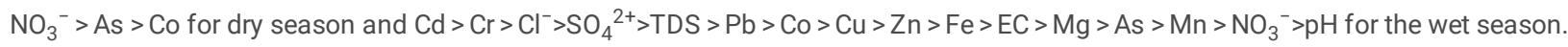

\subsection{Appraisal of water quality using IWQIs}

Based on the outcomes of PCA/FA, the weights (Wi) of each variable acquired are outlined in Tables 2 and 3. The earlier cited works (Sutadian et al. 2017; Tripathi and Singgal 2019; Islam et al. 2020a and Janin et al. 2020; Wu et al., 2021) reported that a science-based appraisal of variables weights based on the PCA/FA approach relies mostly on two conditions; first, the existence of inter-association among variables, and second, as a minimum 150-300 cases required for the analysis. While the chosen variables showed strong significant associations among these variables and the tested cases were 250 , the computed variable weights would be reasonable to make new irrigation water quality indices (IWQImin-1, IWQImin-2, and IWQImin-3). On the other hand, the results of Shannon entropy theory, the entropy weight (wj), and information entropy (ej) of each variable obtained are shown in Table 1. The previous studies (Amiri et al. 2014; Islam et al. 2017a; 2020a) also showed that the entropy-based assessment of variables can deal with uncertainty influencing the water quality and successfully use in water quality evaluation based on entropy weight because of its robustness, reliability, and precision. Information entropy helps in extracting the amount of information by measuring the equality, diversity, flexibility, complexity, interactivity, and redundancy of the random datasets. Also, it quantifies the uncertainty or randomness in the data-sets (Singh 2014). Entropy weight of water quality parameters determines its impacts on the water quality. Parameters with the lowest entropy value and highest entropy weight have maximum impact on overall quality (Islam et al. 2017a)

In the current study, we utilized the entropy weight and information entropy to prepare entropy irrigation water quality indices (EWQIs), the obtained objective weight would be justified. 
Table 3

Varimax rotated component matrix for water quality parameters

Dry Season

\begin{tabular}{|c|c|c|c|c|c|}
\hline $\begin{array}{l}\text { Eigen } \\
\text { value }\end{array}$ & $\begin{array}{l}\text { Relative } \\
\text { Eigen } \\
\text { value } \\
\text { (REV) }\end{array}$ & Variable & $\begin{array}{l}\text { Loading } \\
\text { value }\end{array}$ & $\begin{array}{l}\text { Relative } \\
\text { loading } \\
\text { value } \\
\text { (RLV) }\end{array}$ & $\begin{array}{l}\text { Weight } \\
\text { (REV*RLV) }\end{array}$ \\
\hline
\end{tabular}

Initial 16 water quality parameters

\section{Wet Season}

\begin{tabular}{|c|c|c|c|c|}
\hline $\begin{array}{l}\text { Eigen } \\
\text { value }\end{array}$ & $\begin{array}{l}\text { Relative } \\
\text { Eigen } \\
\text { value } \\
\text { (REV) }\end{array}$ & Variable & $\begin{array}{l}\text { Loading } \\
\text { value }\end{array}$ & $\begin{array}{l}\text { Relative } \\
\text { loading } \\
\text { value } \\
\text { (RLV) }\end{array}$ \\
\hline
\end{tabular}

Initial 16 water quality parameters

\begin{tabular}{|c|c|c|c|c|c|c|c|c|c|c|c|c|c|}
\hline 1 & 5.97 & 0.39 & $\mathrm{pH}$ & 0.27 & 0.18 & 0.07 & 1 & 5.25 & 0.33 & EC & 0.39 & 0.30 & 0.10 \\
\hline & & 0.39 & EC & 0.33 & 0.22 & 0.08 & & & 0.33 & TDS & 0.38 & 0.20 & 0.07 \\
\hline & & 0.39 & $\mathrm{Mn}$ & 0.27 & 0.18 & 0.07 & & & 0.33 & NO3- & 0.37 & 0.20 & 0.07 \\
\hline & & 0.39 & $\mathrm{Fe}$ & 0.28 & 0.18 & 0.07 & & & 0.33 & SO4- & 0.33 & 0.20 & 0.07 \\
\hline & & 0.39 & SO42- & 0.37 & 0.24 & 0.09 & & & 0.33 & $\mathrm{Cl}-$ & 0.3 & 0.10 & 0.03 \\
\hline & & & Total & 1.52 & 1 & & & & & Total & 1.77 & 1.00 & \\
\hline 2 & 4.53095 & 0.3 & TDS & 0.31 & 0.28 & 0.08 & 2 & 3.84 & 0.24 & $\mathrm{pH}$ & 0.26 & 0.20 & 0.05 \\
\hline & & 0.3 & $\mathrm{Cr}$ & 0.34 & 0.31 & 0.09 & & & 0.24 & $\mathrm{~Pb}$ & 0.35 & 0.30 & 0.07 \\
\hline & & 0.3 & Co & 0.20 & 0.18 & 0.05 & & & 0.24 & $\mathrm{Mn}$ & 0.35 & 0.30 & 0.07 \\
\hline & & 0.3 & $\mathrm{Cu}$ & 0.26 & 0.23 & 0.07 & & & 0.24 & $\mathrm{Fe}$ & 0.33 & 0.20 & 0.05 \\
\hline & & & Total & 1.11 & 1 & & & & & Total & 1.29 & 1.00 & \\
\hline 3 & 2.0918 & 0.14 & $\mathrm{~Pb}$ & 0.34 & 0.27 & 0.04 & 3 & 1.81 & 0.11 & Co & 0.39 & 0.40 & 0.05 \\
\hline & & 0.14 & $\mathrm{Cd}$ & 0.58 & 0.46 & 0.06 & & & 0.11 & $\mathrm{Cu}$ & 0.4 & 0.40 & 0.05 \\
\hline & & 0.14 & $\mathrm{Cl}-$ & 0.33 & 0.26 & 0.04 & & & 0.11 & As & 0.26 & 0.20 & 0.02 \\
\hline & & & Total & 1.25 & 1 & & & & & Total & 1.05 & 1.00 & \\
\hline 4 & 1.6104 & 0.11 & $\mathrm{Mg}$ & 0.3 & 0.42 & 0.04 & 4 & 1.31 & 0.08 & $\mathrm{Cd}$ & 0.33 & 0.20 & 0.02 \\
\hline & & 0.11 & NO3- & 0.41 & 0.58 & 0.06 & & & 0.08 & $\mathrm{Mg}$ & 0.36 & 0.30 & 0.02 \\
\hline & & & Total & 0.71 & 1 & & & & 0.08 & $\mathrm{Zn}$ & 0.54 & 0.50 & 0.04 \\
\hline 5 & 1.048 & 0.07 & $\mathrm{Zn}$ & 0.63 & 0.78 & 0.05 & & & & Total & 1.23 & 1.00 & \\
\hline & & 0.07 & As & 0.18 & 0.22 & 0.02 & 5 & 0.98 & 0.06 & $\mathrm{Cr}$ & 0.63 & 1.00 & 0.12 \\
\hline Total & 15.25 & 3.84 & Total & 0.81 & 1 & & Total & 13.19 & 3.25 & Total & 0.63 & 1.00 & \\
\hline Short & sted $10 \mathrm{pa}$ & ameter & luded in & MDS & & & Short & sted 10 & aramet & ncludec & he MDS & & \\
\hline 1 & 5.25 & 0.39 & EC & 0.33 & 0.47 & 0.08 & 1 & 5.25 & 0.33 & EC & 0.39 & 0.34 & 0.10 \\
\hline & & 0.39 & SO42- & 0.37 & 0.53 & 0.09 & & & & TDS & 0.38 & 0.33 & 0.07 \\
\hline & & & Total & 0.7 & 1 & & & & & NO3- & 0.37 & 0.32 & 0.07 \\
\hline 2 & 4.53 & 0.3 & TDS & 0.31 & 0.48 & 0.08 & & & & Total & 1.14 & 1.00 & \\
\hline & & 0.3 & $\mathrm{Cr}$ & 0.34 & 0.52 & 0.09 & 2 & 3.84 & 0.24 & $\mathrm{~Pb}$ & 0.35 & 0.50 & 0.07 \\
\hline & & & Total & 0.65 & 1 & & & & & $\mathrm{Mn}$ & 0.35 & 0.50 & 0.07 \\
\hline 3 & 2.09 & 0.14 & $\mathrm{~Pb}$ & 0.34 & 0.27 & 0.04 & & & & Total & 0.7 & 1.00 & \\
\hline & & 0.14 & $\mathrm{Cd}$ & 0.58 & 0.46 & 0.06 & 3 & 1.81 & 0.11 & Co & 0.39 & 0.49 & 0.05 \\
\hline & & 0.14 & $\mathrm{Cl}-$ & 0.33 & 0.26 & 0.04 & & & & $\mathrm{Cu}$ & 0.40 & 0.51 & 0.00 \\
\hline & & & Total & 1.25 & 1 & & & & & Total & 0.79 & 1.00 & \\
\hline 4 & 1.61 & 0.11 & $\mathrm{Mg}$ & 0.3 & 0.42 & 0.05 & 4 & 1.31 & 0.08 & $\mathrm{Mg}$ & 0.36 & 0.40 & 0.03 \\
\hline & & 0.11 & NO3- & 0.41 & 0.58 & 0.07 & & & & $\mathrm{Zn}$ & 0.54 & 0.60 & 0.04 \\
\hline & & & Total & 0.71 & 1 & & & & & Total & 0.9 & 1.00 & \\
\hline 5 & 1.05 & 0.07 & $\mathrm{Zn}$ & 0.63 & 1 & 0.05 & 5 & 0.98 & 0.06 & $\mathrm{Cr}$ & 0.63 & 1.00 & 0.12 \\
\hline Total & 13.19 & 3.25 & Total & 0.63 & 1 & & Total & 13.19 & 3.25 & Total & 0.63 & 1.00 & \\
\hline
\end{tabular}


As displayed in Fig. 2a, the IWQI-1 varied from 19.08 to 77.22, which denotes poor to good quality water for the dry season. The temporal distribution of water quality classes (Fig. 3a) elucidates that $22.4 \%$ of surface water samples were demarcated as good, $61.7 \%$ as moderate, $14.5 \%$ as low and $1.4 \%$ poor quality water. Likewise, the IWQI-2 implied low to good water qualities, since index values ranged from 18.08 to 76.22 . Similarly, $60.8 \%$ of the water samples were divided as good, $31.3 \%$ as moderate, $7.2 \%$ as low and $0.7 \%$ as poor quality, respectively. These nearby outcomes between the two methods can be contributed to the same weights come from the two approaches. In the case of the IWQI-min, the studied sixteen water quality variables recommended by FAO were decreased to ultimately shortlisted ten indicators/variables to be added in the LDS using the PCA/FA method (Table 3). The LDS comprised of EC, TDS, Pb, Cd, $\mathrm{Cr}, \mathrm{Zn}, \mathrm{Mg}, \mathrm{Cl}^{-}, \mathrm{NO}_{3}{ }^{-}$and $\mathrm{SO}_{4}{ }^{2-}$. The IWQImin-1 varied from 5.4 to 97.11 , which means poor to excellent water qualities. Water quality classes were

demarcated into five grades, i.e., excellent, good, moderate, low and poor, that responsible for $28.7 \%, 47.6 \%, 14.8 \%, 5.5 \%$ and $3.4 \%$ of the total water samples, respectively. The IWQImin-2 varied from 40.32 (low) to 90.44 (good) water qualities. The temporal distribution of water quality classes was as followed: good (81.6\%), moderate (14.8\%), low (3.4\%) and poor (0.2\%), respectively. The IWQImin-3 ranged from 2.44 to 94.10 , which denotes poor to excellent water qualities. Besides, the EWIQI-1 varied from 1.32 (poor) to 86.37 (good) that accounted for $45.30 \%$ (good), $47.42 \%$ (moderate), $5.77 \%$ (low) and $1.50 \%$ (poor) of the total samples, respectively. Similarly, the EWQI-2 ranged from 0.08 (poor) to 60.62 (moderate) that means $37.04 \%$ (moderate), $60.17 \%$ (low) and $1.50 \%$ (poor), respectively. The low water quality of the Dhaleswari River is triggered by the discharge of urban waste and industrial effluent of the largest industrial center in this area. This finding is confirmed by the other analysis (Hasan et al., 2020), where industrial activities are presented as the major source of waste in this river basin. It can be stated that nonconformity from the good water quality needs in this river basin is because of untreated municipal wastewater. Thus, suitable measures such as the construction of the wastewater treatment plant, and the improvement of the sewerage system are required for maintaining good water quality status (Rahman et al., 2017).

The IWQI-1 varied from 69.92 to 79.09, which means moderate to good quality water in the wet season (Fig. 2b). The temporal distribution of water quality classes (Fig. 3b) exhibits that $96.18 \%$ of water samples were demarcated as good, $3.82 \%$ as moderate water quality. Similarly, in IWQI-2 values varied from 78.08 to 92.59 which denotes $91.37 \%$ as good and $8.63 \%$ as excellent. For the IWQImin-1, the ultimately shortlisted ten variables to be added in the LDS using the PCA/CA results. The LDS comprised of EC, TDS, $\mathrm{Pb}, \mathrm{Mn}, \mathrm{Cr}, \mathrm{Zn}, \mathrm{Mg}, \mathrm{Co}, \mathrm{NO}_{3}{ }^{-}$and $\mathrm{Cu}$. It ranged from 85.21 to 93.42 that accounted for $16.55 \%$ as excellent and $91.37 \%$ as good water quality. The IWQImin-2 varied from 89.31 (good) to 94.85 (excellent). In IWQImin-3, all the water samples showed that the water quality is moderate with the highest value of 57.72. Similarly, the EWQI-1varied from 1.32 (poor) to 92.76 (good) that responsible for $38.69 \%$ (excellent), $48.03 \%$ (good), $3.21 \%$ (moderate), $0.05 \%$ (poor) of the total samples, respectively. In addition, the EWQI-2 ranged from 0.08 (poor) to 85.65 (good) which means 99.99 \% as good water quality. Similar findings were also observed by Jahin et al (2020) in Kafr El-Sheikh river, Egypt. This might be attributed to the fact that the anthropogenic inputs, surface run-off from adjacent municipal areas, upstream water flow, and stormwater drains may trigger this abnormal distribution of IWQI values as well as also the high stream water flow in the Dhaleswari River during the wet season. Our findings can be compared with the cited works performed by many researchers in different regions of the world (Wang et al., 2017; Tripathi and Singal, 2019; Janin et al., 2020; Matta et al., 2020; Wu et al., 2021; Yotova et al., 2021). For example, Bora and Goswami (2017) found that the WQI values were 85.73, 122.47 and 80.75 , respectively during the pre-monsoon, monsoon, and post-monsoon season of the Kolong River, Assam, India. Wang et al. (2017) reported that the WQI values varied from 9.40$1734.79,61.85-1803.64,57.82-1691.85$, and 55.14-2204.90, respectively among the water samples in the Huaihe River, Anhui, China. Islam et al. (2020b) found that EWQIs values ranged from 35.65 (Meghna River) to 159.55 (Teesta River) which was accounted for $26.7 \%$ as an excellent, $53.03 \%$ as good, $3.33 \%$ as moderate, $10 \%$ as poor, and $6.7 \%$ as unfit for drinking purpose in the surface water of six river basin in Bangladesh. Seasonally, significant water quality fluctuation occurs in the dry season compared to the wet season.

\subsection{Comparison among water quality indices for both seasons}

The results revealed that no significant statistical differences were observed between IWQI-1 and IWQI-2 at a 99\% confidence level. Besides, the values of R2 and RMSE were 0.99 and 0.954 , respectively, suggesting a high association between the measured values from both methods. This can be ascribed to the same function of PCA/FA as they could group distinct variables in terms of correlation coefficient (Bodrud-Doza et al. 2016). Conversely, FA decreases the influence of less important parameters attained from PCA and the original group of parameters is obtained after varimax rotating the axis confined by PCA assessment (Giri and Singh 2014). We observed various variations of WQI values in both seasons. This may be due to the high stream water flow, heavy rainfall in the monsoon season, reducing concentrations of water quality parameters in the wet season. However, the dry season showed many fold higher IWQI values in all water samples than the wet season. Although, a single number cannot tell the entire story of surface water quality; many other contributing variables are not included in the index including $\mathrm{Na}$, $\mathrm{Ca}$, and $\mathrm{K}$. Besides, a water quality index based on several significant variables can provide a simple and robust indicator of water quality. Thus, it can be stated that weights come from communality after FA are superior to that obtained from PCA according to their degree of multi-associated variables. Besides, no significant statistical differences were found among IWQImin-1, IWQImin-2, IWQImin-3, EWQI-1, and EWQI-2 at a $99 \%$ confidence level.

This implies that the estimated LDS was good representative of the new variables, and can be utilized effectively to trace the spatial and temporal variations in the surface water quality in the study sites. The PCA/FA is well documented in the existing literature as a robust technique to produce a more unbiased LDS for water bodies (Tripathi and Singal 2019). In the validation dataset, the IWQI-1 and IWQI-2 showed good performances and close associations with other indices such as EWIQI-1 and EWIQ1-2 with equal $\mathrm{R}^{2}$ values of $0.59,0.57,0.89$ and 0.88 and RMSE values of 13.85, 14.49, 15.95 and 15.09 respectively (Fig. 4). In this study, for the dry seasons, two variables under PC1, PC2 and PC4 (EC, TDS, $\mathrm{Cr}_{1} \mathrm{Mg}^{2+}, \mathrm{SO}_{4}{ }^{2-}$ and $\mathrm{NO}_{3}{ }^{-}$) were obtained in the LDS except for PC3 (three

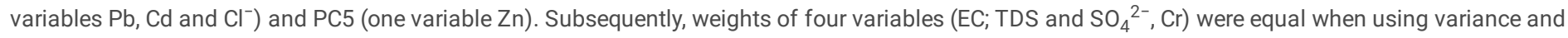
eigenvalues and factor loading. Therefore, the two weighting tools had a near trend pattern. In the case of IWQImin-1 vs IWQImin-3, and EWQI-1 vs EWQI-2, values of $R^{2}$ and RMSE were $0.64,0.53$ and $21.76,25.35$, respectively, at $99 \%$ confidence level and hence the performances of these indices were reasonably poorer than IWQI-1 and IWQI-2. Moreover, IWQI-1 and IWQI-2 were marginally wider than those of other indices at a 95\% confidence level. This implies also that especially IWQI-1 showed lower influences on uncertainty for predicting surface water quality (Wu et al. 2021).

Page $12 / 22$ 
For the wet season, there were no significant statistical differences between IWQI-1 and IWQI-2 at a 99\% confidence limit. In addition, values of R2 and RMSE were 0.84 and 12.38, respectively, suggesting a strong association between the measured values but weak performance from both methods. Besides, no significant statistical differences were observed among IWQImin-1, IWQImin-2, IWQImin-3, EWQI-1, and EWQI-2 at a 99 \% confidence level.

In the testing dataset, the IWQI-1 showed weak performances but strong associations with the other index such as IWQImin-1, IWQImin-2, and IWQImin-3, with equal R2 values of $0.73,0.69$, and 0.64 and RMSE values of 15.93, 18.88, and 18.78, respectively (Fig. 5). However, IWQI-2 exhibited excellent performance and good association with IWQImin-1 $\left(R^{2}=0.57, \mathrm{RMSE}=4.25, \mathrm{p}<0.01\right)$. For the wet seasons, two variables under PC2, PC3 and PC4 (Pb, Mn, Co, Cu, Mg and Zn) were retained in the LDS except for PC1 (three variables $\mathrm{EC}$, TDS and $\mathrm{NO}_{3}{ }^{-}$) and $\mathrm{PC} 5$ (one variable $\mathrm{Cr}$ ). Then, weights of three variables $\left(\mathrm{EC}\right.$, $\mathrm{TDS}^{-}$and $\mathrm{NO}_{3}{ }^{-}$) were equals based on variance, eigenvalues and factor loading analysis. Therefore, the two weighting tools had an almost trend pattern. In the case of IWQImin-1 vs IWQImin-2, IWQImin-1 vs IWQImin-3, IWQImin-2 vs IWQImin-3, and EWQI-1 vs EWQI-2, values of R2 were $0.83,0.93,0.91$ and 0.58 and RMSE values of $3.06,34.6437 .57$, and 13.89 , respectively at $99 \%$ confidence level and hence the performances of these indices were rationally poorer than IWQI-1 and IWQI-2 except for IWQImin-1 and IWQImin-2. Moreover, both IWQI-1 and IWQI-2 were slightly larger than those of other indices at a 95\% confidence level. This implies also that especially IWQI-2 showed lower influences to uncertainty for predicting surface water quality (Wu et al. 2018). This is because the PCA is based solely on linear dataset structures, whereas the FA is based on a particular tool. The FA shows that dataset is based on the underlying factors of the tool and that data total variance can be decomposed into that accounted for by general and single factors (OCED 2008). Jahin et al. (2020) also found a similar linear trend among the water quality parameters in their work. IWQI-1 and IWQI-2 are robust because of limited parameters requirement, which also lessens analytical cost (Sanchez et al. 2007). Interestingly, our suitable IWQI method is not devised from multiple regression analyses, which acted a vital role in significant variable selection and performed well in the Dhaleswari River.

\subsection{Spatial patterns of water quality indices}

Spatial autocorrelation was used to perform on water quality indices for assessing their spatial differences during both seasons (Table 4). In the dry season, non-significant negative Moran's I values ( $p>0.1)$ were identified for all indices in the studied basin, which might be attributed to the spatial heterogeneity in pollutant loads and identify water quality development policies. In contrast, a non-significant weak positive spatial autocorrelation ( $p>0.1)$ was detected for IWQImin-2, indicating the rational spatial integration in the study region.

In the wet season, a highly significant spatial autocorrelation $(\mathrm{p}<0.1)$ was identified for IWQImin-3, which was negatively associated $($ Moran's I=-0.1696 and Z value=-1.793), suggesting that geographically neighboring locations had an analogous value of IWQImin-3 water quality. Similarly, the Moran's I values exhibited a weak negative autocorrelation at a confidence level of $p>0.1$ in all indices except for IWQI-2 and EWQI-2 which indicate a localized effect on water quality indices (Islam et al. 2020a). The differences in spatial autocorrelation among the water quality indices might be ascribed to surface water discharge dynamics and flush out of monsoonal rain impacts (Islam et al. 2017a, Liu and Mao 2020).

Table 4

Spatial autocorrelation analysis between IWQIs and EWQIs in the study area

\begin{tabular}{|llllll|}
\hline Dry season & & & & & \\
\hline & Moran's I & Variance & Z score & P value & Distribution \\
\hline IWQI-1 & -0.77877 & 0.852975 & -0.79811 & 0.42481 & Random \\
\hline IWQI-2 & -0.73733 & 0.851735 & -0.75378 & 0.450981 & Random \\
\hline Min-1 & -1.14411 & 0.891459 & -1.16763 & 0.242955 & Random \\
\hline Min-2 & 0.339754 & 0.68144 & 0.462051 & 0.644045 & Random \\
\hline MEWIQ-3 & -0.65893 & 0.79892 & -0.69059 & 0.489824 & Random \\
\hline MEWIQI-2 & -0.65893 & 0.79892 & -0.69059 & 0.489824 & Random \\
\hline Wet season & & 0.798333 & -0.14507 & 0.884657 & Random \\
\hline & Moran's I & Variance & Z score & P value & Distribution \\
\hline IWQI-1 & -0.07662 & 0.81884 & -0.03863 & 0.969189 & Random \\
\hline IWQI-2 & 0.06138 & 0.854593 & 0.111469 & 0.911244 & Random \\
\hline Min-1 & -0.69994 & 0.851235 & -0.71348 & 0.475548 & Random \\
\hline Min-2 & -0.92087 & 0.829134 & -0.96555 & 0.334268 & Random \\
\hline Min-3 & -1.69688 & 0.852172 & -1.79304 & 0.072966 & Dispersed \\
\hline MEWIQI-1 & -0.22045 & 0.664189 & -0.21938 & 0.826358 & Random \\
\hline MEWIQI-2 & 0.06203 & 0.12341 & 0.295183 & 0.767854 & Random \\
\hline
\end{tabular}

\subsection{Factor contribution analysis}


As stated in the earlier section, in the current study, 10 water quality variables have been retained in the LDS based on the PCA/CA, which is incorporated in the irrigation water quality using the random forest (RF) model. The contribution or importance of each variable has been computed by the RF model. The relative contribution/importance of all the physicochemical variables in irrigation water quality can be appraised from Table 5. Though the magnitude to influence on the water quality for 10 physicochemical variables is not equal, they are echoed by the mean decrease accuracy of Gini index values. For the dry season, among physicochemical variables, predicted underlying LDS and Cd have little influence on the optimal IWQI-1 model. On the contrary, predictor variables e.g., $\mathrm{NO}_{3}{ }^{-}, \mathrm{Mg}^{2+}, \mathrm{Cl}^{-}, \mathrm{Pb}$, and $\mathrm{Cr}$ are having a higher influence on the prediction of irrigation water quality in the dry season. $\mathrm{NO}_{3}{ }^{-}$is a very crucial parameter that elucidated most of the variance in water quality of Chillan River, Chile (Debels et al. 2005) and the Dongjing River, China (Sun et al. 2016). For the wet season, among 10 variables, $\mathrm{Mn}, \mathrm{Pb}, \mathrm{Mg}^{2+}, \mathrm{Cr}$, and $\mathrm{Cu}$ are having a greater influence on the prediction of the best model. However, underlying variables such as $\mathrm{Zn}$ and $\mathrm{NO}_{3}{ }^{-}$have little influence on the prediction of irrigation water quality in the wet season.

Table 5

Relative impotence of physicochemical parameters calculated by the RF model

\begin{tabular}{|llll|}
\hline \multicolumn{2}{|l|}{ IWQI-1 for dry season } & \multicolumn{2}{l|}{ IWQI-2 for wet season } \\
\hline Variable & Mean decrease Gini & Variable & Mean decrease Gini \\
\hline NO3 & 1043.13 & $\mathrm{Mn}$ & 69.73 \\
\hline $\mathrm{Mg}$ & 763.45 & $\mathrm{~Pb}$ & 34.43 \\
\hline $\mathrm{Cl}$ & 387.43 & $\mathrm{Mg}$ & 31.24 \\
\hline $\mathrm{Pb}$ & 363.75 & $\mathrm{Cr}$ & 10.39 \\
\hline $\mathrm{Cr}$ & 320.93 & $\mathrm{Cu}$ & 10.37 \\
\hline $\mathrm{EC}$ & 225.82 & $\mathrm{TDS}$ & 6.44 \\
\hline $\mathrm{Zn}$ & 172.09 & $\mathrm{Co}$ & 5.55 \\
\hline $\mathrm{SO} 4$ & 138.78 & EC & 4.23 \\
\hline TDS & 137.05 & Zn & 3.2 \\
\hline $\mathrm{Cd}$ & 108.9 & NO3 & 2.3 \\
\hline
\end{tabular}

\section{Discussion}

Water quality deterioration is one of the greatest environmental challenges which led to detrimental effects on human health and the aquatic ecosystem. Although fast development and industrialization have produced large quantities of industrial effluents including liquid waste, the amounts are still unclear because of a lack of proper monitoring programs from respective water regularity bodies. The surface water of the Dhaleshwari River in central Bangladesh has deposited those wastes, especially liquid waste. Worsening of water quality utilized for irrigation purposes is a serious issue in the river basin. The deterioration of water resources could have substantial impacts on ecological quality, health risk, and even climate warming (Ayers and Westcot 1985). Besides, the agrochemical and fertilizers utilized in an adjacent agricultural crop field is another crucial contaminating agent in the area, though the current advancement of the Integrated Pest Management (IPM) policies stressed lessening the use of pesticides.

The present work will be used for future surface water quality appraisal for irrigation purposes as well as the local water development board in the studied area. First, the outcome explained the water quality status of the river using the IWQIs and EWQIs models. Related practitioners and local government departments could get information about water quality conditions and its spatiotemporal distribution at a local scale rather than a regional scale. Second, we have retained 10 important parameters in the LDs using the PCA/FA and IWQI method varied significantly. Third, surface water quality state was comparatively worse in the dry season and good in the wet season based on IWQI classification. Fourth, we found the important variables influencing water quality, e.g., $\mathrm{NO}_{3}{ }^{-}, \mathrm{Mg} \mathrm{Cl}^{-}, \mathrm{Pb}$ and $\mathrm{Cr}$ in the dry season and $\mathrm{Mn}, \mathrm{Pb}, \mathrm{Mg}, \mathrm{Cr}$ and $\mathrm{Cu}$ in the wet season based on the RF model which comprised the most appropriate IWQI method in the study region. Thus, the waters in the tested river basin are partly suitable for irrigation purposes based on IWQIs and EWQIS. Much focus needs on the river basin with poor quality of surface water due to the river water is yet used for irrigation and domestic purposes. The earlier studies suggest the adoption of a suitable management plan of the cleansing program and the implementation of strict water law due to poor-quality water affected in the studied region (Ferreira et al. 2020).

The IWQIs methods were accurately better than the EWQIs model based on 10 physicochemical variables. Thus, local water development authority should be conscious of these crucial variables during any monitoring and appraisal program. Furthermore, the tentative IWQI-1 and IQWI-2 have a good performance in this vital basin in Dhaleshwari River, which will contribute to enhancing understanding of surface water quality knowledge in a similar river basin. This study helps policymakers in science-based policy making because the application of statistical approach aids in the reduction of the subjectivity of the index generation and prepares it more objective in characteristics.

Irrigation water quality indices e.g., sodium adsorption ratio, soluble sodium percentage, residual sodium carbonate and total hardness (Raghunath 1987; Islam et al. 2017a; Rahman et al. 2017) are mostly related to the water salinity and hardness which are affiliated to the soil fertility and plants' yields only. Natural processes like sea-level raise triggered by global warming, source rock-water interactions as well as local geology of water basins and catchment areas mostly govern the above-mentioned irrigation indices where meq/L contents of $\mathrm{Na}^{+}$, and $\mathrm{Ca}^{2+}$ are rigorously used for water quality evaluation. However,

Page $14 / 22$ 
anthropogenic processes can release a wide range of chemical entities e.g., $\mathrm{Pb}, \mathrm{Cd}, \mathrm{Cr}, \mathrm{Mn}, \mathrm{Co}, \mathrm{Zn}, \mathrm{As} \mathrm{NO}_{3}{ }^{-}, \mathrm{SO}_{4}{ }^{2-}$ etc. to the aquatic system which can potentially contaminate plant's edible parts and enter into the human food-chain along with the deterioration of irrigation soil quality. Instead of routine monitoring of widely used IWQIs (utilizing meq/ $\mathrm{L}$ contents of $\mathrm{Na}^{+}, \mathrm{K}^{+}$and $\mathrm{Ca}^{2+}$ ), objective based anthropogenic impacts on irrigation water quality relative to the FAO 29 standard values were used in this study. On the other hand, $\mathrm{Na}^{+}, \mathrm{K}^{+}$and $\mathrm{Ca}^{2+}$, does not have significant impact along with using heavy metals: $\mathrm{Pb}$, $\mathrm{Cd}, \mathrm{Cr}, \mathrm{Mn}, \mathrm{Co}, \mathrm{Cu}, \mathrm{Zn}$, As for the development of irrigation water quality and entropy weighted indices. Therefore, $\mathrm{Na}^{+}, \mathrm{K}^{+}$and $\mathrm{Ca}^{2+}$, were not included for irrigation water quality and entropy weighted indices development study.

\section{Conclusion}

We developed a well-establish IWQIs and EWQIs for surface water suitability for agricultural purposes concerning representative variables suggested by FAO29 standard and a well-accepted method, namely, NSFWQI and entropy theory. Seasonality to spatiotemporal changes in physicochemical parameters in surface water during both seasons has been investigated in this work. Spatial patterns of water quality indices were appraised using Moran's autocorrelation index. The outcomes of Shannon entropy theory implied that $\mathrm{Mg}, \mathrm{Cr}$, TDS, and $\mathrm{Cl}^{-}$for the dry season and $\mathrm{Cd}_{1} \mathrm{Cr} \mathrm{Cl}^{-}$and $\mathrm{SO}_{4}{ }^{2-}$ for the wet season were recognized as the main pollutants, triggering water quality degradation. PCA and FA have been employed efficiently in two crucial parts, e.g., least variable selection and allocating their weights on one hand. Shannon entropy theory has been employed efficiently in two steps, i.e., entropy weight of all variables and their information entropy on the other hand to develop EWQI-1 and EWQI-2 for both the seasons. Both PCA and FA identified the weights for the preliminary sixteen variables added in computing IWQI-1 and IWQI-2, respectively, with the final method being suggested. The IWQIs exhibited an analogous trend with the EWQIs model that implied water quality classes varied from poor to good qualities. The PCA/FA lessened the dimensionality of multiple parameters to develop a well-demonstrative LDS of EC, TDS, $\mathrm{Cr}, \mathrm{Zn}, \mathrm{Mg} \mathrm{SO}_{4}{ }^{2-}, \mathrm{Pb}, \mathrm{Cd}, \mathrm{Cl}^{-}$, and $\mathrm{NO}_{3}{ }^{-}$for dry season and $\mathrm{Pb}, \mathrm{Mn}, \mathrm{Cr}, \mathrm{Co}, \mathrm{Cu}, \mathrm{Mg}, \mathrm{Zn}, \mathrm{EC}, \mathrm{TDS}$, and NO${ }_{3}{ }^{-}$for the wet season to be added in introducing IWQImin-1, IWQImin-2, and IWQImin-3 for both seasons. The performance of IWQIs is depicted comparatively higher than EQWIs because of inclusiveness. The IWQImin with weights come from PCA developed in good measuring and predicting water quality compared to weights originated from FA. The variables chosen in the computation of IWQImin can be evidently estimated, which will considerably reduce monitoring time and cost of data collection and analysis of a huge number of variables. On a spatial scale, IWQImin-3 was statistically negatively correlated with the wet season (Moran's I value >0). Our research has also identified the physicochemical variables including $\mathrm{NO}_{3}{ }^{-}, \mathrm{Mg} \mathrm{Cl}^{-}, \mathrm{Pb}$ and $\mathrm{Cr}$ may influence the irrigation water quality for the dry season and $\mathrm{Mn}, \mathrm{Pb}, \mathrm{Mg}$, and $\mathrm{Cr}$ for the wet season using RF model in the Dhaleshwari River basin, hence justifying further large basin-scale analysis.

\section{Declarations}

\section{Acknowledgement}

The authors are grateful to the authority of the Institute of National Analytical Research and Service (INARS), BCSIR, Dhaka, Bangladesh for providing analytical laboratory facilities, and other logistic and technical supports to conduct this research work. The authors extend their appreciation to the Deanship of Scientific Research at King Khalid University for funding this work through Research Group under grant number (R.G.P.2 /194/42).

\section{Ethical approval}

Not applicable

\section{Consent to Participate}

Not applicable

\section{Consent to Publish}

Not applicable

\section{Data availability}

Data are available upon request on the corresponding author

\section{Funding}

This work has been carried out under the institutional Research and Development (R and D) project entitled "Evaluation of the level of toxic elements in water, soil and plants and their impacts on human health and environment" approved by the authority of Bangladesh Council of Scientific and Industrial Research (BCSIR), Dhaka, Bangladesh (Reference No.: 39.02.0000.011.14.128.2020/636, Date: 29.12.2020, Serial No. 72, Unit Code: INARS-03) in the financial year of 2020-2021.

\section{Author contributions}

A.R.M.T., M.A.B.S., and M. H., designed, planned, conceptualized, drafted the original manuscript, and R.K., M.W.N.S., and M.B., was involved in statistical analysis, interpretation; A.R.M.T.I., M.M.R., and M.A.A., contributed instrumental setup, data analysis, validation; A.R.M.T., M.S.R., M.S.H., and M.H., contributed to editing the manuscript, literature review, proofreading; M.A.B.S., M.Y.M., J.M., and A.R.M. T.I., were involved in software, mapping, and proofreading during the manuscript drafting stage. 


\section{Conflict of interest}

The authors declare that they have no conflict of interest.

\section{References}

Ahmed N, Bodrud-Doza M, Islam ARMT, Hossain S, Moniruzzaman M, Dev N, Bhuiyan, MAQ (2019) Appraising spatial variations of As, Fe, Mn and NO3 contaminations associated health risks of drinking water from Surma basin, Bangladesh, Chemosphere, 218,726-740 Doi: 101016/jchemosphere201811104

Ahsan MA, Satter F, Siddique MAB, Akbor MA, Ahmed S, Shajahan M, Khan R (2019) Chemical and physicochemical characterization of effluents from the tanning and textile industries in Bangladesh with multivariate statistical approach Environmental monitoring and assessment, 191(9), 575

APHA (American Public Health Association) (2012) Standard Methods for the Examinationof Water and Waste Water Rice, EW, Baird, RB, Eaton, AD, Clesceri, LS, (Eds) $22^{\text {th }}$ edn Washington, DC: American Public Health Association, American Water Works Association, Water Pollution Control Federation

Ayers RS, Westcot DW (1994) Water quality for agriculture FAO Irrigation and Drainage Paper 29 Revision, Rome, Italy

Banglapedia (2018) National Encyclopedia of Bangladesh Asiatic Society of Bangladesh, Dhaka

Bhuiyan MAH, Bodrud-Doza M, Islam ARMT, Rakib MA, Rahman MS, Ramanathan AL (2016) Assessment of groundwater quality of Lakshimpur district of Bangladesh using water quality indices, geostatistical methods, and multivariate analysis Environ Earth Sci, 75, 1020 doi:101007/s12665-016-5823-y

Bodrud-Doza M, Islam ARMT, Ahmed F, Das S, Saha N, Rahman MS (2016) Characterization of groundwater quality using water evaluation indices, multivariate statistics and geostatistics in central Bangladesh Water Sci 30, 19-40

Breiman L, (2001) Random Forests Machine Learning 45, 5-32

Brown RM, McClelland NI, Deininger RA, Tozer RG (1970) Water quality index-do we dare? Water Sew Works 117 (10), 339-343

Debels P, Figueroa R, Urrutia R, Barra R, Niell X (2005) Evaluation of water quality in the Chilla'n River (Central Chile) using physicochemical parameters and a modified water quality index, Environmental Monitoring and Assessment, 110, 301- 322

DoE (Department of Environment) (1997) Industrial Effluents Quality Standard for Bangladesh Environmental conservation rules, Government of the People's Republic of Bangladesh, Dhaka

Dutta S, Dwivedi A, Kumar MS (2018) Use of water quality index and multivariate statistical techniques for the assessment of spatial variations in water quality of a small river Environ Monit Assess 190 (718)

Ewaid SH, Kadhum SA, Abed SA, Salih RM (2019) Development and evaluation of irrigation water quality guide using IWQG V1 software: A case study of AlGharraf Canal, Southern Iraq Environ Technol Innov 13, 224-232

FAO (2008) The State of the World's h Land and Water Resources for Food and Agriculture (SOLAW) - Managing Systems at Risk Food and Agriculture Organization of the United Nations, Rome and Earthscan, London

Ferreira M da Silva, Fontes MPF, Pacheco AA, Lima HN, Santos JZL (2020) Risk Assessment of Trace Elements Pollution of Manaus Urban Rivers Sci Total Environ 709, 134471

Giri S, Singh AK (2014) Risk assessment, statistical source identification and seasonal fluctuation of dissolved metals in the Subarnarekha River India J Hazard Mater 265, 305-314

Habib MA, Islam ARMT, Bodrud-Doza M, Mukta FA, Khan R, Siddique MAB, Phoungthong K, Techato K (2020) Simultaneous appraisals of pathway and probable health risk associated with trace metals contamination in groundwater from Barapukuria coal basin, Bangladesh Chemosphere 242,125183

Härdle WK, Simar L (2015) Factor analysis In: Härdle, WK, Simar, L (Eds), Applied Multivariate Statistical Analysis Springer Berlin Heidelberg, Berlin, Heidelberg, $359-384$

Hasan MM, Ahmed MS, Adnan R, Shafiquzzaman M (2020) Water quality indices to assess the spatiotemporal variations of Dhaleshwari river in central Bangladesh, Environmental and Sustainability Indicators, 8, 100068

Hossain M, Patra PK (2020) Water pollution index - A new integrated approach to rank water quality, Ecol Indic, 117, 106668

Islam ARMT, Ahmed N, Bodrud-Doza M, Chu R (2017b) Characterizing groundwater quality ranks for drinking purposes in Sylhet district, Bangladesh, using entropy method, spatial autocorrelation index, and geostatistics, Environment Science and Pollution Res, 24(34), 26350-26374 doi: 101007/s11356-0170254-1

Islam ARMT, Islam HT, Mia MU, Khan R, Habib MA, Bodrud-Doza M, Siddique MAB, Chu R (2020c) Co-distribution, possible origins, status and potential health risk of trace elements in surface water sources from six major river basins, Bangladesh Chemosphere, 249, 126180

Page $16 / 22$ 
Islam ARMT, Mamun AA, Rahman MM, Zahid A (2020a) Simultaneous comparison of modified-integrated water quality and entropy weighted indices: Implication for safe drinking water in the coastal region of Bangladesh, Ecol Indic, 113, 106229, doi: 101016/jecolind2020106229

Islam ARMT, Shen S, Bodrud-Doza M, Rahman SM (2017a) Assessing irrigation water quality in Faridpur district of Bangladesh using several indices and statistical approaches, Arabian Journal of Geoscience, 10:418 doi: 101007/s12517-017-3199-2

Islam A R M T, Ahmed N, Bodrud-Doza M, Chu R (2017c) Characterizing groundwater quality ranks for drinking purposes in Sylhet district, Bangladesh, using entropy method, spatial autocorrelation index, and geostatistics Environmental Science and Pollution Research, 24(34), 26350-26374

Islam ARMT, Siddiqua MT, Zahid A, Tasnim SS, Rahman MM (2020b) Drinking appraisal of coastal groundwater in Bangladesh: An approach of multi-hazards towards water security and health safety, Chemosphere, 254,126933

Islam ARMT, Talukdar S, Mahato S et al, (2020d) Flood susceptibility modelling using advanced ensemble machine learning models, Geoscience Frontiers, doi: 101016/jgsf202009006

Jahin HS, Abuzaid AS, Abdellatif AD (2020) Using multivariate analysis to develop irrigation water quality index for surface water in Kafr El-Sheikh Governorate, Egypt Environ Tech Inno 17, 100532

Khan AA, Paterson R, Khan H (2003) Modification and application of the CCMEWQI for the communication of drinking water quality data in Newfoundland and Labrador 38th, Central Symposium on Water Quality Research, Canadian Association on Water Quality, Burlington, Canada

Liu Y, Mao D (2020) Integrated assessment of water quality characteristics and ecological compensation in the Xiangjiang River, south-central China Ecol Indic, 110, 105922

Matta G, Nayak A, Kumar A et al, (2020) Water quality assessment using NSFWQI, OIP and multivariate techniques of Ganga River system, Uttarakhand, India Appl Water Sci 10, 206

Misaghi F, Delgosha F, Razzaghmanesh M, Myers B (2017) Introducing a water quality index for assessing water for irrigation purposes: A case study of the Ghezel Ozan River Sci Total Environ 589, 107-116

OECD (2008) Handbook on Constructing Composite Indicators: Methodology and User Guide OECD, France

Panda S, Chakraborty M, Misra SK (2016) Assessment of social sustainable development in urban India by a composite index Int J Sustain Built Environ 5, $435-450$

Pei-Yue L, Hui Q, Jian-Hua W (2010) Groundwater qualityassessment based on improved water quality index in Pengyangplain, Ningxia, northwest China E-J Chem 7(S1), S209-S216

R Core Team (2014) R: A Language and Environment for Statistical Computing R Foundation for Statistical Computing, Vienna, Austria http://wwwRprojectorg/

Raghunath IIM (1987) Groundwater $2^{\text {nd }}$ edition; Wiley Eastern Ltd, New Delhi, India

Rahman MS, Azad MAK, Hasanuzzaman M, Salam R, Islam ARMT, Rahman MM, Hoque MMM (2020) How air quality and COVID-19 transmission change under different lockdown scenarios? A case from Dhaka city, Bangladesh, Sci Total Environ, 143161, doi: 101016/jscitotenv2020143161

Rahman MS, Islam ARMT (2019) Are precipitation concentration and intensity changing in Bangladesh overtimes? Analysis of the possible causes of changes in precipitation systems Sci Total Environ 690, 370-387

Saha N, Bodrud-doza M, Islam ARMT et al, (2020) Hydrogeochemical evolution of shallow and deeper aquifers in central Bangladesh: arsenic mobilization process and health risk implications from the potable use of groundwater, Environmental Earth Science, DOI: 101007/s12665-020-09228-4

Salam R, Islam ARMT (2020) Potential of RT, Bagging and RS ensemble learning algorithms for reference evapotranspiration prediction using climatic datalimited humid region in Bangladesh, J Hydrol, 590, 125241

Salem ZE, AlTemamy AM, Salah MK, Kassab M (2019) Evaluation of water resources qualities for agriculture irrigation in Abu Madi area, northern middle Nile Delta In: Negm, AM (Ed), Conventional Water Resources and Agriculture in Egypt Springer International Publishing AG, Cham, Switzerland, pp 277-316

Sánchez E, Colmenarejo M F, Vicente J, Rubio A, García MG, Travieso L, Borja R (2007) Use of the water quality index and dissolved oxygen deficit as simple indicators of watersheds pollution Ecol Indic, 7(2), 315-328

Shannon Claude E (1948) A mathematical theory of communication Bell Syst Tech J 27, 379-423

Siddique MAB, Alam MK, Islam, S. et al. (2020) Apportionment of some chemical elements in soils around the coal mining area in northern Bangladesh and associated health risk assessment. Environmental Nanotechnology, Monitoring \& Management, 14, 100366. https://doi.org/10.1016/j.enmm.2020.100366

Singh KR, Goswami AP, Kalamdhad AS, Kumar B (2020) Development of irrigation water quality index incorporating information entropy, Environment, Development and Sustainability, 22, 3119-3132 
Singh S, Ghosh NC, Gurjar S, Krishan G, Kumar S, Berwal P (2018) Index-based assessment of suitability of water quality for irrigation purpose under Indian conditions Environ Monit Assess 190, 29

Singh VP (2014) Entropy theory in hydraulic engineering: An introduction American Society of Civil Engineers

Sun W, Xia C, Xu M, Guo J, Sun G (2016) Application of modified water quality indices as indicators to assess the spatial and temporal trends of water quality in the Dongjiang River Ecol Indic 66, 306-312 https://doiorg/101016/jecolind201601054

Sutadian AD, Muttil N, Yilmaz AG Perera BJC (2016) Development of river water quality indices-a review Environ Monit Assess 188, 58

Sutadian AD, Muttil N, Yilmaz AG, Perera BJC (2017) Using the Analytic Hierarchy Process to identify parameter weights for developing a water quality index Ecol Indic 75, 220-233

Tripathi M, Singal SK (2019) Use of Principal Component Analysis for parameter selection for development of a novel Water Quality Index: A case study of river Ganga India Ecol Indic 96, 430-436

Tyagi S, Sharma B, Singh P, Dobhal R (2013) Water quality assessment in terms of water quality index Am J Water Res 1, 34-38

Wang J, Liu G, Liu H, Lam PKS (2017) Multivariate statistical evaluation of dissolved trace elements and awater quality assessment in the middle reaches of Huaihe River, Anhui, China Sci Total Environ 583, 421-431

Wu Z, Lai X, Li K (2021) Water quality assessment of rivers in Lake Chaohu Basin (China) using water quality index, Ecol Ind, 121, 107021

Wu Z, Wang X, Chen Y, Cai Y, Deng J (2018) Assessing river water quality using water quality index in Lake Taihu Basin China Sci Total Environ 612, 914-922

Xiao J, Jin Z, Wang J (2014) Geochemistry of trace elements and water quality assessment of natural water within the Tarim River Basin in the extreme arid region, NW China J Geochem Explor, 136, 118-126

Yotova G, Varbanov M, Tcherkezova E, Tsakovski S (2021) Water quality assessment of a river catchment by the composite water quality index and selforganizing maps, Ecol Indic, 120, 106872

Zardari N H, Ahmed K, Shirazi S M, Yusop ZB (2015) Weighting Methods and their Effects on Multi-Criteria Decision Making Model Outcomes in Water Resources Management Springer Briefs in Water Science and Technology doi:101007/978-3-319-12586-2

\section{Figures}




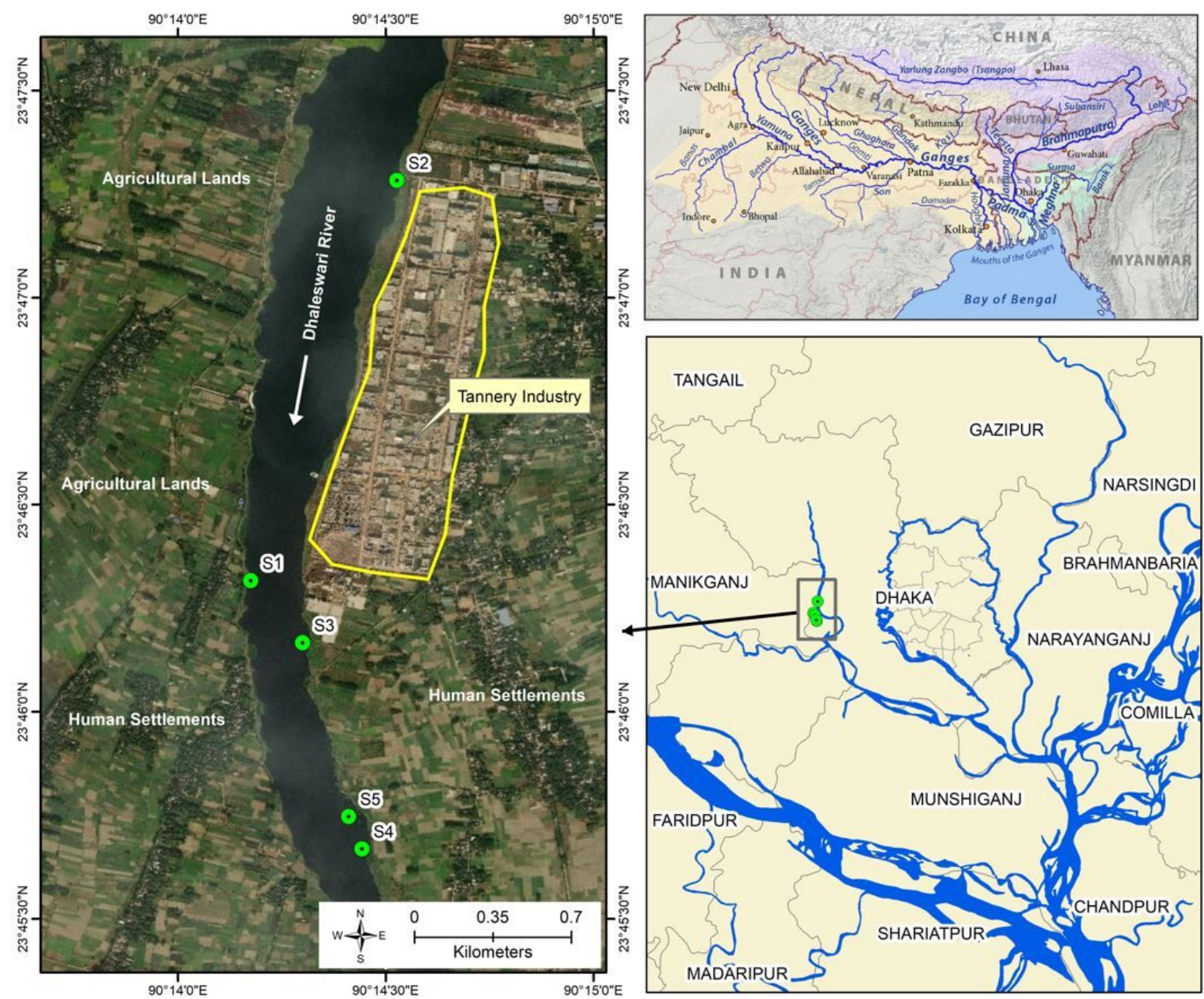

Figure 1

Location map showing the study area and sampling sites. Note: The designations employed and the presentation of the material on this map do not imply the expression of any opinion whatsoever on the part of Research Square concerning the legal status of any country, territory, city or area or of its authorities, or concerning the delimitation of its frontiers or boundaries. This map has been provided by the authors. 
a) Dry Season

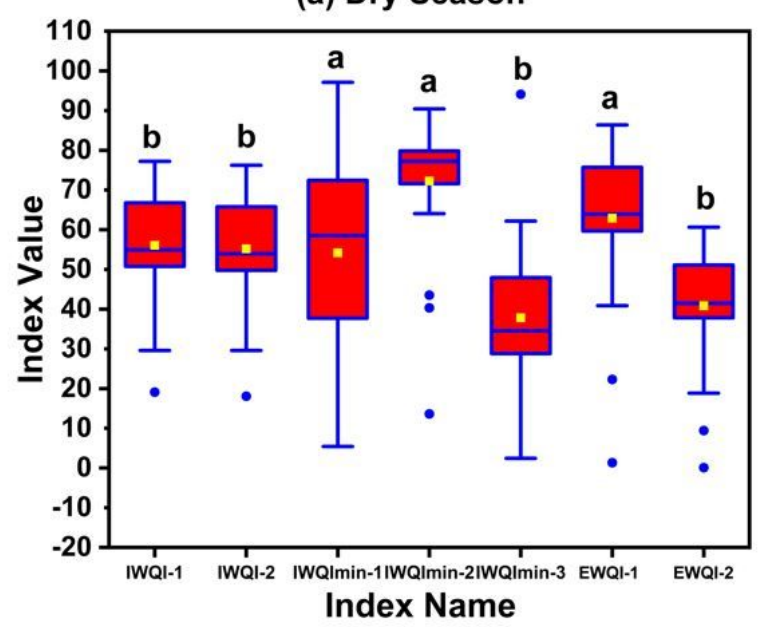

(b) Wet Season

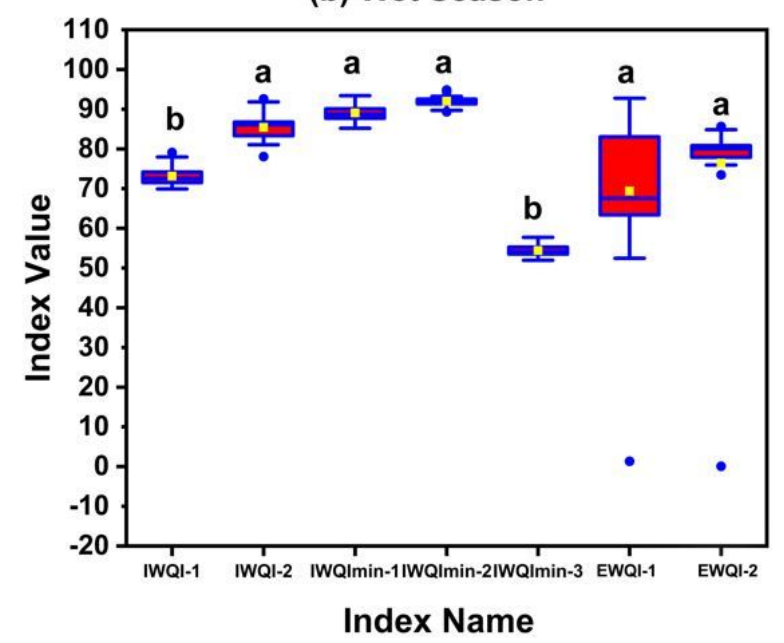

Figure 2

Values of IWQIs and EWQIs in the Dhaleswari River basin in both seasons (similar letters denote no significant difference at $p<0.01$ ). 
(a) Dry season

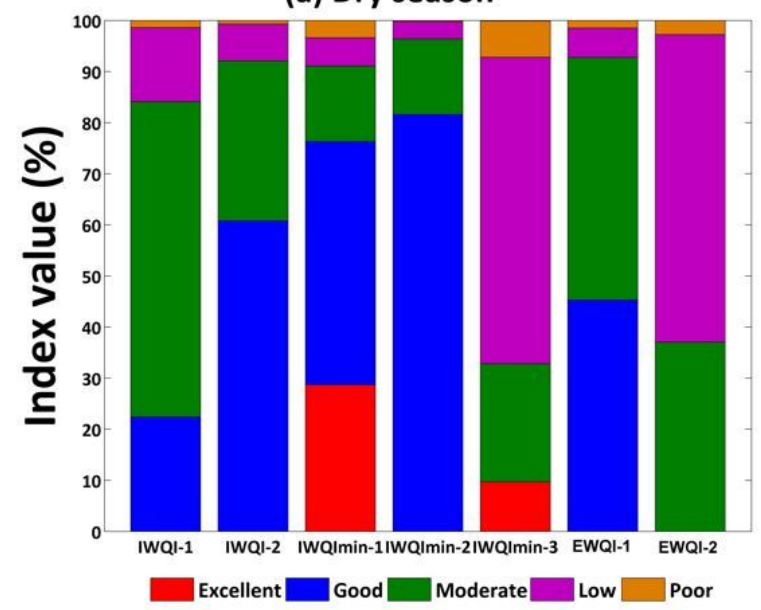

(b) Wet season

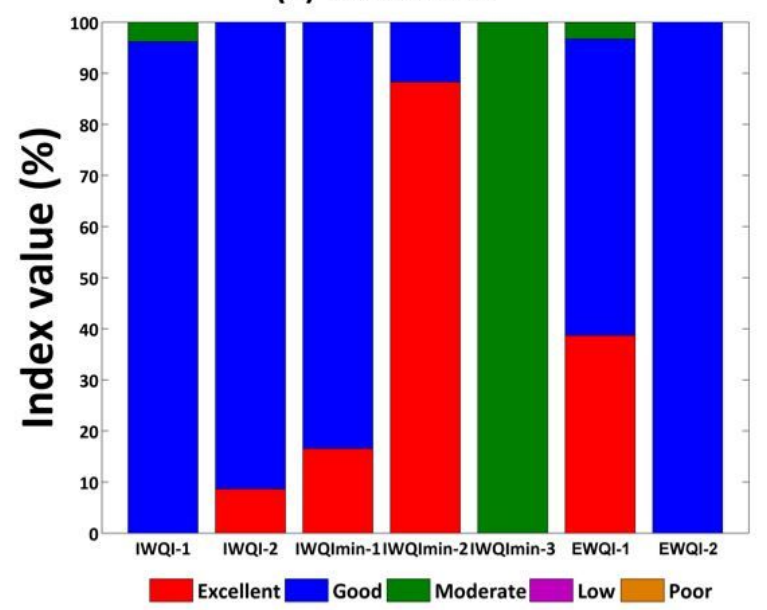

Figure 3

Distribution of water quality classes (\%) among water samples in the dry and wet seasons
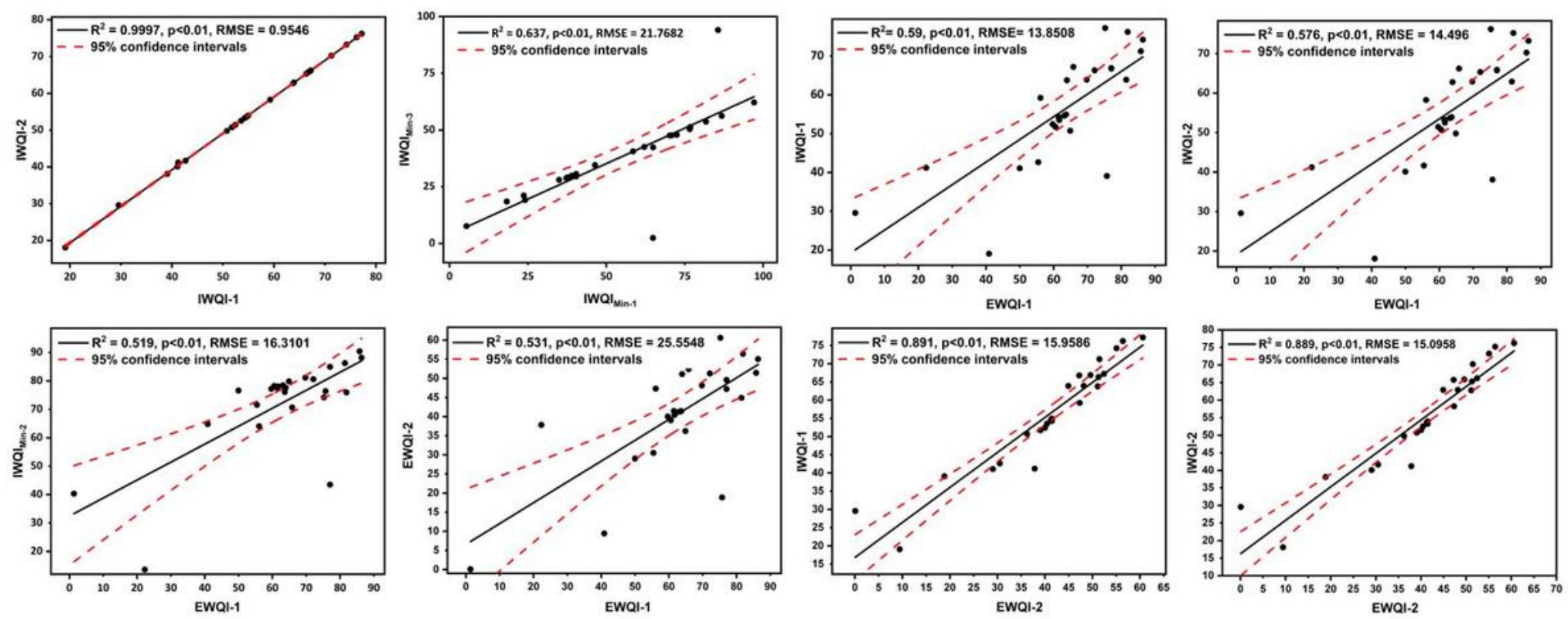

Figure 4

Associations among water quality indices in the dry season. Black solid line represents the linear coefficient of determination (R2) where the red dashed lines represent $95 \%$ confidence interval. 

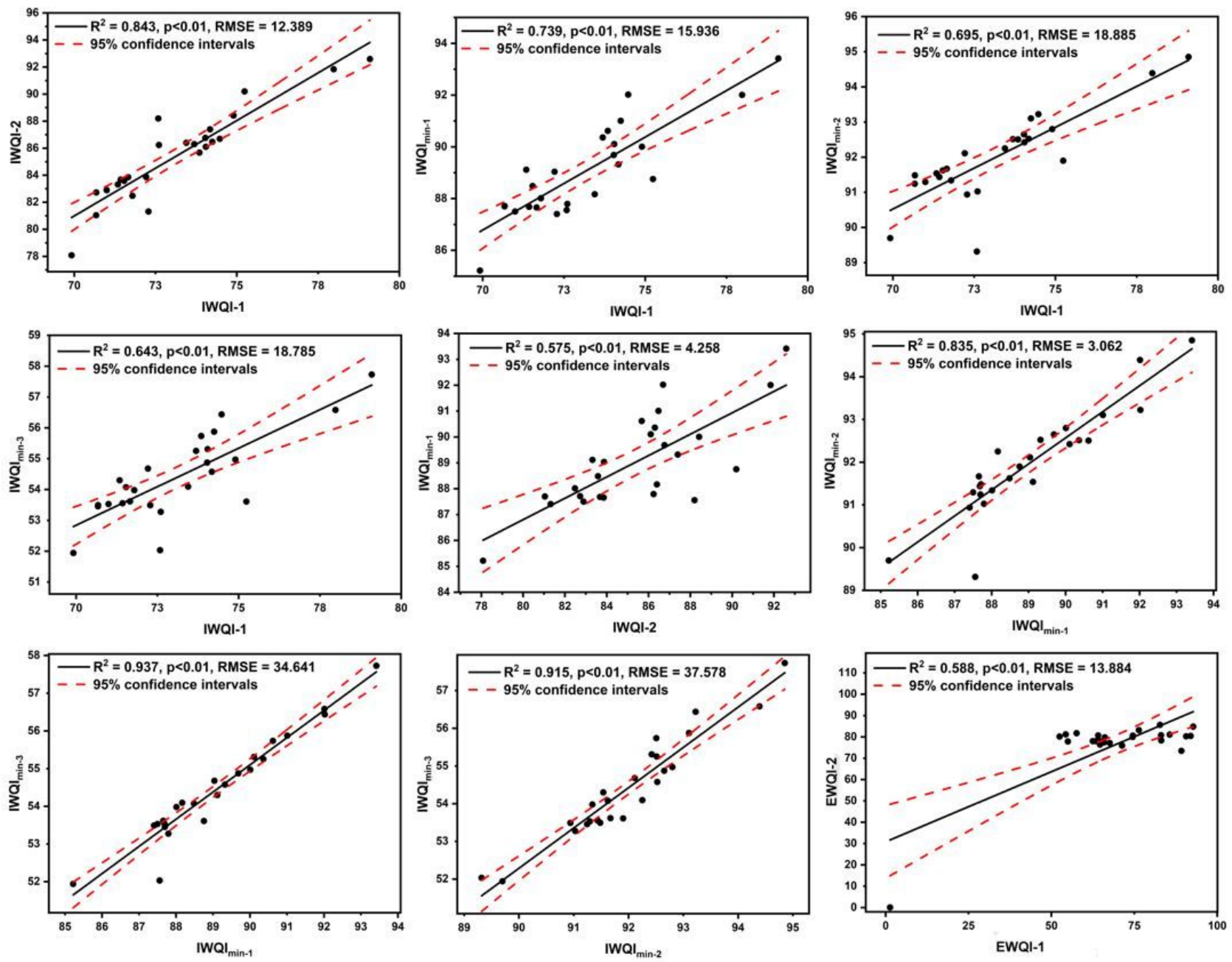

Figure 5

Associations among water quality indices in the wet season. Black solid line represents the linear coefficient of determination (R2) where the red dashed lines represent $95 \%$ confidence interval. 